Buca Eğitim Fakültesi Dergisi, 2021, say1 51, s.137-159

Araştırma Makalesi

\title{
Öğretmen Adayları İçin Dijital Okumaya Yönelik Tutum Ölçeği (DOTÖ): Geçerlik ve Güvenirlik Çalışması
}

\author{
Attitude Scale Towards Digital Reading (DRAS) for Preservice \\ Teachers: Validity and Reliability Study
}

\author{
Ibrahim Halil YURDAKAL ${ }^{l}$, Fatma SUSAR KIRMIZI ${ }^{2}$
}

\begin{abstract}
${ }^{1}$ Sorumlu Yazar, Doç. Dr., Temel Eğitim Bölümü, Eğitim Fakültesi, Pamukkale Üniversitesi, Türkiye,iyurdakal@pau.edu.tr, (https://orcid.org/0000-0002-6333-5911)

${ }^{2}$ Prof. Dr., Temel Ĕ̈itim Bölümü, Ĕ̈itim Fakültesi, Pamukkale Üniversitesi, Türkiye, fsusar@pau.edu.tr, (https://orcid.org/0000-0002-0426-1908)
\end{abstract}

Geliş Tarihi: 31.08 .2020

Kabul Tarihi: 10.04.2021

\section{ÖZ}

Ekrandan gerçekleştirilen dijital okuma son yıllarda oldukça yaygınlaşmış olup kullanım oranı giderek artmaktadır. Sembollerin yanı sıra hareketli görüntüler hatta ses de içeren dijital metinler her yaştan bireyi kendisine çekmektedir. Olumlu ve olumsuz nitelikler içeren dijital okumanın, zihinsel gelişimi ne kadar etkilediği; göz ve beyin arasında nasıl bir etkileşim sağladığı henüz tespit edilebilmiş değildir. Yaşamın neredeyse her alanında önemli/vazgeçilmez olan telefonlar, tabletler, diz üstü bilgisayarlar vb. gençleri dijital okumaya teşvik etmektedir. İnternetin -bilgi kirliliğine rağmen- her türlü bilgiyi içinde barındırması, hızlı bir şekilde güncellenebilmesi, iletişim olanaklarını artırması ve keyifli zaman geçirmeyi sağlaması gibi özellikleri genç bireyler için oldukça cezbedicidir. Gençlerin bu konuya ilişkin ilgilerinin yüksek olması konuyu araştırmaya değer kılmaktadır. Dijital okuma tutumuna ilişkin geliştirilecek ölçme aracının konunun bilimsel alt ölçekte değerlendirilmesinde etkili olacağ ${ }_{1}$ düşüncesi ile hareket edilmiştir. $\mathrm{Bu}$ çalışmanın amacı öğretmen adaylarının dijital okumaya ilişkin tutumlarını değerlendirmeye yönelik geçerli ve güvenilir bir ölçme aracı geliştirmektir. Ölçme aracının geliştirilmesi sürecinde öncelikle alanyazın taraması yapılmış ve öğretmen adaylarına dijital okumaya ilişkin açık uçlu soru formu hazırlanarak adayların konu hakkındaki görüşleri alınmıştır. Alanyazın taraması ve öğretmen adaylarının açıklamalarından elde edilen veriler ışığında yargılar/maddeler oluşturulmuş ve bunlar bir havuzda toplanmıştır. 40 maddeden oluşan taslak ölçek uzman görüşüne sunulmuş ve yapılan düzeltmelerden sonra 3 madde ölçme aracından çıkarılmıştır. Sonuç olarak pilot uygulama öncesi 37 madde ile aday ölçme aracı ortaya çıkarılmıştır. Öğretmen Adayları İçin Dijital Okumaya Yönelik Tutum Ölçeği’nin (DOTÖ) geliştirmesi çalışmaları Covid-19 sürecinde alınan tedbirlere uygun bir şekilde gerçekleştirilmiştir. Bu nedenle katılımcılara internet üzerinden ulaşılmıştır. Birebir etkileşim söz konusu olmamıştır. Pilot çalışma süreci Ege Bölgesi'nde yer alan, 2 farklı kamu üniversitesinin (A üniversitesinden 319 ve B üniversitesinde 169 ögretmen adayı çalışmaya dâhil edilmiştir) eğitim fakültelerinde, on bir farklı ana bilim dalında, 3 ve 4. sınıflarda öğrenim gören öğretmen adayları ile gerçekleştirilmiştir. DOTÖ’yü geliştirme uygulamaları için AFA kapsamında 324; DFA kapsamında 164 olmak üzere toplamda 488 öğretmen adayına (195'i erkek, 293'ü kadın) ulaşılmıştır. Ölçeğin faktör yapısının belirlenmesi için hem açımlayıcı (AFA) hem de doğrulayıcı faktör analizi (DFA) yapılmıştır. Analizler sonucunda ölçeğin KMO değeri 0.818; Cronbach's Alpha değeri 0,956; Spearman-Brown korelasyon değeri 0,92; Guttman Split-Half değeri 0,923; Anova Tukey's Nonadditivity ,000, Hotelling's T-Squared ,000 ve Intraclass Correlation Coefficient değeri ,000 bulunmuş olup ölçek iki alt ölçekten oluşmaktadır. İlk alt ölçek ölçeğin varyansının \%33,22'ini; ikinci alt alt ölçek ölçeğin varyansının ise \%21.08'ini açıkladığı görülmektedir. Birinci alt ölçekte yer alan maddelerin faktör madde yük değerleri 0,81 ile 1-0,535 arasında; ikinci alt faktörde yer alan maddelerin faktör yük değerleri ise 0,791 ile $-0,476$ arasında değişmektedir. İki faktörün toplam açıkladığ 1 varyans değeri ise \%54,30'dur. Doğrulayıcı faktör analizi sonrası IFI değeri 0.92; NFI 0.89; NNFI 0.92; IFI 0.92; 
CFI 0.92; REMSEA 0.12 ve X2/sd değeri 2.75 olarak belirlenmiştir. Ölçek son hali ile iki alt ölçek ve 31 sorudan oluşmaktadır.

Anahtar Kelimeler: Dijital okuma, öğretmen adayı, ölçek geliştirme, geçerlik, güvenirlik.

\begin{abstract}
Digital reading on the screen has become widespread in recent years, as well as increasing its popularity. In addition to symbols, digital texts, including moving images and even sound, attract individuals of all ages. How digital reading, which includes positive and negative qualities, affects mental development; The interaction between the eye and the brain has not yet been determined. Phones, tablets, laptops etc. are an important / indispensable phenomenon in almost every aspect of life. encourages young people to read digitally. The features of the Internet, such as containing all kinds of information, being able to update quickly, increasing communication opportunities and providing a pleasant time - despite the information pollution - are very attractive for young individuals. The high interest of young people in this subject makes the subject worth researching. It is thought that the measurement tool to be developed for digital reading attitude will be effective in evaluating the subject in a scientific sub-scale. The aim of this study is to develop a valid and reliable measurement tool to evaluate pre-service teachers' attitudes towards digital reading. In the process of developing the assessment tool, firstly the literature was reviewed and an openended question form about digital reading was prepared for the pre-service teachers and their opinions on the subject were taken. Judgments / items were formed in the light of the data obtained from the literature review and the preservice teachers' explanations and they were collected in a pool. The draft scale consisting of 40 items was submitted to expert opinion and 3 items were removed from the measurement tool after corrections were made. As a result, the candidate assessment tool was created with 37 items before the pilot application. Studies to develop the Attitude Scale for Digital Reading (DOTÖ) for Teacher Candidates were carried out in accordance with the measures taken in the Covid-19 process. Therefore, the participants were reached over the internet. There was no one-to-one interaction. The pilot study process was carried out in the education faculties of 2 different public universities (319 from University A and 169 from University B), located in the Aegean Region, with pre-service teachers studying in eleven different departments, 3rd and 4th grades. 324 within the scope of EFA for developing DOTÖ; Within the scope of CFA, a total of 488 teacher candidates (195 male, 293 female), including 164, were reached. Both exploratory (EFA) and confirmatory factor analysis (CFA) were performed to determine the factor structure of the scale. As a result of the analysis, the KMO value of the scale was 0.818; Cronbach's Alpha value is 0.956; SpearmanBrown correlation value of 0.92; Guttman Split-Half value of 0.923; Anova Tukey's Nonadditivity was found to be .000, Hotelling's T-Squared, 000 and Intraclass Correlation Coefficient value, 000 , and the scale consists of two subscales. $33.22 \%$ of the variance of the first subscale scale; It is seen that the second subscale explains $21.08 \%$ of the variance of the scale. The factor item load values of the items in the first subscale were between 0.81 and 1-0.535; The factor loading values of the items in the second sub-factor vary between 0.791 and -0.476 . The total variance value explained by the two factors is $54.30 \%$. IFI value after confirmatory factor analysis is 0.92; NFI 0.89; NNFI 0.92; IFI 0.92; CFI 0.92; REMSEA was determined as 0.12 and $\mathrm{X} 2$ / sd value was determined as 2.75 . The scale consists of two subscales and 31 questions in its final form.
\end{abstract}

Keywords: Digital reading, teacher candidate, scale development, validity, reliability.

\title{
GİRIŞ
}

Dijital aygıtların yaygınlaşması ile birlikte gazete, dergi, kitap gibi bütün yazılı kaynaklar ekrandan okunur olmuştur. Artık ya cep telefonundan ya da tuşlarına tıklayarak gerçekleştirilen ekranlardan okuma oldukça olağan bir şekilde yaşamın içinde yer almaktadır. Bu cihazlar tek bir tuşla, ulaşmak istenilen bütün kaynakları, büyük bir kolaylıkla bireylerin önüne sermektedir. Böylece taşınması zaman zaman zor gelen gazeteler, kitaplar, güncel yayınlar, dergiler dijital aygıtın içinde her zaman okunmaya hazır hâlde bulunmaktadır.

Dijital okuma hareketli görüntüler, ses gibi özellikler sunduğu için bireylerin birden fazla duyu organını etkilemektedir. Bu açıdan ele alındığında anlamlandırma sürecinde çok fazla 
seçenek sunduğu söylenebilir. Dijital kaynakların saklanması da basılı kaynaklara göre daha kolay olmaktadır. Bu nedenle dijital okuma özellikle de gençler arasında her geçen gün biraz daha yaygınlaşmaktadır. Gençler basılı kitapların arasında kaybolmak yerine ceplerinde bir kütüphane ile gezmeyi tercih etmektedir. Raflardaki kitaplara yalnızca aynı ortamda ulaşılırken dijital ortamdaki sayfalar her an ulaşılmaya hazır bir şekilde beklemektedir. Boz (2018), MEB ile işbirliği içerisinde Türkiye genelinde 73.053 lise öğrencisi ile yaptığ çalışmada dijital okuma ve basılı kaynaktan okumaya ilişkin görüşleri tespit etmeyi amaçlamıştır. Araştırmadan elde edilen bulgulara göre, öğrencilerin \% 38,1'i okumak için dijital cihaz kullandıklarını dile getirirken, \% 61,9'i okumak için dijital cihaz kullanmamaktadır. Akçaoğlu Saydım (2017), MEB ile işbirliği yaparak öğretmenlerin dijital okuma kültürüne ilişkin bir değerlendirme yapmayı amaç edinmiştir. Araştırmada bir web sayfası üzerinden 92.525 ilkokul, ortaokul ve lise öğretmenine ulaşılmıştır. Araştırmaya katılan öğretmenlerin \%58,5'i okumak için dijital cihaz kullandıklarını belirtirken, \%41,5'i okumak için dijital cihaz kullanmadıklarını ifade etmiştir.

Bilgisayar teknolojisinin ortaya çıkması, özellikle internet ağının yeni bir bilgi depolama ve dağıtma işlevini üstlenmesi, kitap ve buna bağlı olarak okuma eylemlerinin de değişmesine ön ayak olmuştur. Teknolojik alanda yaşanan gelişmeler nesiller üzerinde okuma alışkanlığının yeni şekillerle ortaya çıkmasına yol açmaktadır. Kitabın baskı düzeyinde gerekli olup olmadığının tartışılmaya başlandığı bir süreçte okuma alışkanlığının yeni anlayışlar doğrultusunda kendini göstermesi kaçınılmaz görülebilir (Yılmaz, 2009). Boz (2018) tarafından yapılan araştırmada öğrenciler, dijital metinleri yararlı gördüklerini ifade etmiştir. Öğrenciler, dijital metinlerin ilgi çekici olmasından ötürü bu metinlere dikkatlerini vermelerinin daha kolay olduğunu belirtmiştir. Öğrenciler ayrıca, ekrandan okumanın okuma sürecini kolaylaştırdığını, istenilen bilgiye hızlı ve kolay ulaşabildiklerini, dijital metinleri daha kolay anladıklarını, bilgilerin kolaylıkla taşınabildiğini ve göz gezdirmenin kolay olduğunu belirtmişlerdir. Chou'ya (2011) göre elektronik metinler işlevsellik kazandıkça akademik yaşamda da ön plana çıkmaya devam edecektir. Söz konusu araştırmada yüksek lisans öğrencilerinin dikkat gerektiren metinleri bilgisayar ekranından okumayı tercih etmedikleri sonucuna ulaşılmıştır. Çünkü ekranda okunan metinler strateji kullanımını güçleştirmektedir. Ancak çoğu öğrencinin atıfta bulunacağı metinlere ekrandan ulaşmayı tercih ettiği de belirlenmiştir.

Tüm olumlu ve olumsuz yönlerine rağmen dijital dünyada büyüyen gençler bu konudaki okuma becerilerini geliştirmek için de ister istemez bir çaba göstermek durumunda kalmaktadır. Dijital okuma dijital yetkinlik gerektiren bir alandır. Bu becerilerin geliştirilmesi bilgisayar ve bilgi teknolojilerinin oldukça önemli olduğu bir yüzyıl için gereklilik olarak görülebilir. Diğer taraftan çağdaş toplum olmanın da bir göstergesidir (Carvani, Cartelli, Fini ve Ranieri, 2008; Chou, 2011; Jacobs, 2013; Katz ve Macklin, 2007; Şahenk Erkan, Balaban Dağal ve Tezcan, 2015). Gençlerin okuma eylemini ekran üzerinde sürdürmesinin pek çok nedeni bulunmaktadır. Toplumda dijital teknolojilerin yaygınlaştığı bir dönemde dünyaya gelmeleri, internetin eğlenceli bulunması, ödev ve proje gibi araştırmaların internet aracılığıyla daha kolay halledilebilmesi gibi pek çok etken bu nedenler arasında gösterilebilir (Liu, 2008; Makhoul, Copti-Mshael, 2015; Mangen, Walgermo ve Bronnick, 2013; Odabaş, Odabaş ve Sevmez, 2018). Bireyin iyi bir okuyucu olması iyi bir dijital okuyucu olacağı anlamına gelmemektedir. Dijital okuma yapmak için teknolojiyi kullanmaya dair birtakım becerilerin de gelişmiş olması gerekmektedir. Ayrıca kişinin dijital okuma yapmaktan haz alması da süreci kolaylaştıran bir başka etkendir.

Medya araçlarındaki önemli değişimler gençlik ve gençlik kültürleri için yeni toplumsal ve teknolojik olanakları da beraberinde getirmiştir. Özellikle cep telefonlarındaki renkli ekran dönüşümü ve yüksek çözünürlüklü bütünleşik kamera teknolojisinin yaygınlaşması dijital okuma ile iç içe yaşayan genç bir kitlenin ortaya çıkmasında önemli bir rol oynamıştır. Artık okullardaki derslerde dahi tahtaya bakıp yazma yerine, tahtada yazılanların cep telefonu aracılığıyla fotoğrafının çekilmesi, ayrıca ders notu olarak kullanılabilecek kaynaklardan çekilen fotoğrafların çeşitli uygulamalar vasıtasıyla işlenip ders notu hâline getirilmesi ve cep telefonları 
belleklerinde PDF dosyası olarak saklanması gibi öğrenme ve kayıt biçimleri ortaya çıkmıştır. $\mathrm{Bu}$ olanağı sağlayan akıllı telefonlar, tabletler ve elektronik kitap okuyucuları teknoloji ile iç içe olan gençleri ekrandan okumaya sevk etmektedir (Asutay ve diğerleri, 2016).

Dijital okuma özellikleri ve temel becerileri genel olarak değerlendirildiğinde bireyin birtakım yetilere sahip olması gerekliliği ortaya çıkmaktadır. Öncelikle birey dijital ortamlardan ve uygulamalardan yararlanarak bilgiye erişebilmelidir. Diğer taraftan bilgiyi kullanmak, değerlendirmek, yeniden oluşturmak ve diğer bireylerle paylaşmak için de çok alt ölçek teknik ve bilişsel yetilere sahip olma gerekliliği söz konusudur (Özel, 2013). Dijital okuma yapabilmek bir takım teknoloji kullanımı becerilerine de sahip olmayı gerektirmektedir.

Teknolojik gelişmeler insanların okuma alışkanlığında da birtakım değişmelere neden olmuştur. Örneğin önceleri bireyler gün içerisinde yalnızca gazete, dergi ya da kitap okumayı tercih ederken son yıllarda bu durum büyük ölçüde değişmiştir. Bireyler internetin kendisine sunduğu olanaklar doğrultusunda pek çok farklı ürünü (gazete, dergi, kitap, bloglar, vb.) peş peşe okuyabilmektedir. Bu durum göz atarak ya da tarama ile okumayı da beraberinde getirmiştir (Birkerts, 1996; Liu, 2012). Ayrıca dijital metinler okuyucuya büyük bir özgürlük de sunmaktadır. Basılı metinler sabittir ancak dijital metinler web sayfası aktif hâle getirildikten sonra kaydırılarak ya da sayfalar arası atlamalar yapılarak okunabilir. Dijital metinlerde ses ve görüntü hareketliliğinin olması da okuyucu için başka bir ilgi çekici yönüdür (Ross, 2002). Bunlar dijital okumanın yalnızca küçük birer parçasıdır. Zaman içerisinde dijital okumaya farklı ögelerin ekleneceği de öngörülebilir. Tüm bunlardan hareketle dijital okumanın okuma alışkanlıkları üzerinde büyük değişimler yaptığı ve yapmaya da devam edeceği kesindir.

Özerbaş ve Kuralbayeva'ya (2018) göre dijital okuryazarlık olarak adlandırılan terim, efektif ve ciddi bir şekilde internet üzerinden araştırma yapmak, değerlendirmek ve çeşitli dijital teknolojilerden yararlanarak bilgi toplamak anlamına gelir. Odabaş, Odabaş ve Sevmez'e (2018) göre dijital okuma; veri, enformasyon ve/veya bilginin dijital araçlar aracılığıyla okunması eylemidir. Dijital okumayı geleneksel okumadan ayıran en belirgin özellik, eylemin ekran üzerinde yapılıyor olmasıdır. $\mathrm{Bu}$ tanımlar ışığında "teknolojik becerileri de kullanarak elektronik aygıtlar üzerinden yazılı metni duyu organları aracılığı ile algılayarak anlamlandırma sürecine dijital okuma" denir.

Okuma sürecinin niteliğini olumlu ya da olumsuz yönde belirleyen etmenlerden biri de tutumdur. Bireyin okumaya yönelik sahip olduğu tutumlar bu konudaki kişisel niteliklerini, odaklanmasını, doyumunu vb. büyük ölçüde etkilemektedir. Okumaya ilişkin tutumun okuduğunu anlama becerisini etkilediğini ortaya koyan pek çok araştırma mevcuttur (Aydoğdu, 2012; Baştuğ, 2014; Mckenna, Kear ve Ellsworth, 1995; Sallabaş, 2008). Tutumlar gözle görülmez ancak gözlenebilen bazı davranışlara yol açabilmektedir. Herhangi bir konuda başarının artışı da tutumların yönü ile ilişkilidir. Tutumun gücü davranışın yönünü belirlemede etkilidir. Bir tutumun güç derecesi yani zihinsel, davranışsal ve duygusal öğeleri yeterince yüksek değilse, nesne ya da duruma ilişkin etkenleri aşıp davranış niteliği kazanması olası değildir. Dijital okuma sürecindeki bilgi ve becerilerin kullanımının kişinin tutumuna bağlı olduğu söylenebilir. Ancak dijital okumaya yönelik tutumun değerlendirilmesi konusunda geliştirilmiş ölçek alan yazında bulunamamıştır.

Alan yazın incelendiğinde tutum kavramına ilişkin pek çok tanım yapılmıştır. Tutum, bir insanın belirli bir davranışı gösterme konusunda sahip olduğu olumlu veya olumsuz hislerine karşıllk gelmektedir (Çelik, 2013, s. 174). Türk Dil Kurumu'na göre tutum bireyin insanlar, olaylar ve cansız varlıklar karşısında takındığı davranış biçimi (TDK, 2021) olarak tanımlamaktadır. Özgüven (2000) ise tutumu; "bireylerin belirli bir kişi, grup, kurum ya da bir düşünceyi kabul ya da reddetme şeklinde gözlenen, duygusal bir hazır oluş hali" şeklinde tanımlamaktadır. Bu tanımların birleştiği nokta, tutumların herhangi bir nesne ya da duruma yönelik olmasıdır. Diğer taraftan tutumlar olumludan olumsuza doğru uzanan bir değerlendirmeyi yansitabilir (Fabrigar, McDonald ve Wegener, 2005). Pratkanis ve Greenwald 
(1989) tutumu, bireylerin bir objeye yönelik olarak iyi, kötü, güzel, çirkin, olumlu veya olumsuz değerlendirmesi şeklinde belirtmiştir. Tavşancıl'a (2014) göre tutum yaşantı ve deneyimler sonucunda bireyde oluşan olumlu ve olumsuz eğilimlerdir. Davranışın şekillenmesi sürecinde oldukça etkilidir. Morris (2015) tutumu düşünce, duygu ve davranış olmak üzere üç bileşen kapsamında ele almıştır. Düşünceyi bir nesneye ilişkin bilgi ve değerlendirmeler; duyguyu nesneyi sevip sevmeme gibi hisler; davranışı da ilgili nesneye yönelik ortaya konulan eylemler olarak ifade etmiştir.

Okumaya dair yüzyıllardır bilinen kuralların değiştiği bir dönem başlamıştır. Bu dönemde okuyucuların dijital okumanın gereklerini karşılayacak yeni becerilere hâkim olması gerekmektedir. Örneğin bilginin kontrol edilemez biçimde ürediği bu dönemde, okuyucuların edindikleri kaynakları doğruluk ve yeterlilik bağlamında değerlendirme becerilerine eskiden olmadığı kadar gereklilik olduğu ortaya çıkmıştır. Dijital okumada karşılaşılan diğer bir sorun da sık sık yaşanan teknik sorunlardır. Bu durum okurlara zaman kaybettirmekte ve hatta okuma eyleminin sonlandırmasına neden olabilmektedir. A ̆g bağlantı sorunları, tarayıcı sorunları, eklenti noksanlıkları, ekran-görüntü uyumsuzlukları, istenmeyen reklamlar, çerezler ve açılır pencereler gibi okuyucuların bilmediği ve/veya bilmek zorunda olmadığı bazı sorunlar, bu dönemin okuma serüvenini başkalaştıran ve zorlaştıran sorunlar arasında yer almaktadır (Odabaş, Odabaş ve Sevmez, 2018). Her şeye rağmen dijital okumanın kendi içinde kolaylık ve zorlukları olduğu göz ardı edilmemelidir.

Alan yazın incelendiğinde dijital okumaya ilişkin olarak şu ölçeklere ulaşılmıştır: Susar Kırmızı (2017) ilkokul 4. sınıf öğrencileri (n=203) ile Ekrandan Okumaya Yönelik Tutum Ölçeği (EKYÖTÖ) geliştirmiştir. "Sağlık, okuma ve okuduğunu anlama, kolaylık, sevgi, etkileyicilik" şeklinde isimlendirilen beş alt ölçekten oluşan ölçekte, ekrandan okumayı ifade eden oplam 29 tutum maddesi yer almaktadır. Ölçeğin Cronbach's Alpha güvenirlik katsayısı birinci alt ölçek için 0,83 ; ikinci alt ölçek için 0,70 ; üçüncü alt ölçek için 0,71 ; dördüncü alt ölçek için 0,82 ; beşinci alt ölçek için 0,77 ve tümü için ise 0,84 olarak hesaplanmıştır.

Güneş ve Susar Kırmızı (2014) lise 10. ve 11. sınıf öğrencileri (n=536) ile E-Kitap Okumaya Yönelik Tutum Ölçeğinin (EKOT) geliştirmiştir. Ölçek olumlu özellikler ve farklllık olmak üzere iki alt ölçek ve 26 maddeden oluşmaktadır. Birinci alt ölçeğe ilişkin faktör yük değerleri 0,76 ile 0,53 arasında, ikinci alt ölçeğe ilişkin faktör yük değerleri ise 0,72 ile 0,58 arasında değişmektedir. Ölçeğin Cronbach's Alpha güvenirlik katsayısı 0,91'dir.

Ulu (2018) tarafından öğretmen adayları ile Ekran Okuma Öz Yeterlik Algl Ölçeği geliştirilmiştir. Toplamda 228 katılımcı ile gerçekleştirilen çalışmada 28 maddeden oluşan ölçek ortaya çıkarılmıştır. Ölçek kendi içinde 4 alt ölçek içermektedir ve Cronbach's Alpha güvenirlik katsayı1s1 0,75’tir.

Baştuğ ve Keskin (2017) öğrencilerin kâğıttan dijitale yazma tutumunu ölçmek için Kâğıttan Dijitale Yazma Tutumu Ölçeğini geliştirmiştir. Araştırma 2534 gönüllü öğrenciyle (712. sınıf) yürütülmüştür. Yapılan analizler sonucunda 12 maddelik dijital ortamlarda yazma tutumu ve 7 maddelik kâğıt ortamında yazma tutumu faktörleri elde edilmiştir. Ölçeğin güvenirlikleri Dijital ortamlarda yazma tutumu alt ölçeği $\alpha=.89$; Kâğıt ortamında yazma tutumu alt ölçeği $\alpha=.75$; ölçeğin tamamı ise $\alpha=.77$ 'dir. Ayrıca ölçeğin tekrar test güvenirlik sonuçları Dijital ortamlarda yazma tutumu alt ölçeği $=.98$; Kağıt ortamında yazma tutumu $=.96$; ölçeğin tamamı ise .97 bulunmuştur.

Bulut ve Karasakaloğlu (2018) öğretmen adayları ile yaptıkları çalışmada Dijital Okuma Eğilimi Ölçeği geliştirmiştir. Toplamda 301 öğretmen adayı ile gerçekleştirilen çalışmada 12 madde ve tek alt ölçekten oluşan ölçek ortaya çıkarılmıştır. Ölçeğin Cronbach's Alpha güvenirlik katsayısı 0,95'tir.

Ata ve Alparslan (2019) Braten, Brandmo ve Kammerer tarafindan 2018 yılinda geliştirilen Internet Tabanlı Okuma Motivasyonu ve Katılım Ölçeğini Türkçeye uyarlamıştır. 
Toplamda 362 öğretmen adayı ile gerçekleştirilen çalışmada 12 maddeden oluşan ölçeğin 4 alt ölçekli bir yapısı olduğu belirlenmiştir. Analiz sonucunda Cronbach's Alpha güvenirlik katsayısı yeterlik alt-alt ölçek için 0,82 ; zorluk alt-alt ölçek için 0,84 ; adanmışlık alt ölçek için 0,86 ve kaçınma alt ölçek içinse 0,83 olarak bulunmuştur.

Sulak (2019) öğretmen adayları, öğretmenler ve eğitimcilerin dijital okuryazarlık becerilerini ölçmek için Dijital Okuryazarlı Ölçeğini geliştirmiştir. Ölçek 5'li Likert tipi bir ölçek olup üç faktör (öğretim teknolojileri, bilgi ve iletişim, teknik) ve 44 maddeden oluşmaktadır. Birinci faktörde toplam 18 madde yer alıp bu maddelerin faktör yükleri 0.367 ile 0.803; ikinci faktörde toplam 15 madde yer alıp bu maddelerin faktör yükleri 0.482 ile 0.675 ; üçüncü faktörde toplam 11 madde yer alıp bu maddelerin faktör yükleri 0.509 ile 0.742 arasında değişmektedir. Birinci faktördeki Cronbach's Alpha katsayıs1 0.92; ikinci faktörün 0.90; üçüncü faktörün ise 0.91 olarak belirlenmiştir.

Dijital okumanın yaygınlaşması özellikle gençler arasında kabul görmesi bu alanın araştırılmasını gerekli kılmaktadır. Dijital okumaya ilişkin ulusal düzeyde var olan ölçeklerin yeterli sayıda olduğunu söylemek pek olası değildir. Özellikle bu okuma alanına yönelik olarak öğretmen adaylarının tutumlarının değerlendirilmesi özel bir önem taşımaktadır. Öğretmen adaylarının dijital okumaya ilişkin olumlu ya da olumsuz bir tutum içerisinde olması ileride kendi öğrencileri üzerinde de etkili olabilir. Dijital okumayı etkili bir şekilde severek yapan bir öğretmen büyük bir olasılıkla öğrencisine bu yönü ile model olacaktır. Bu nedenle öğretmen adaylarının dijital okumaya yönelik tutumlarının geçerli ve güvenilir bir ölçekle değerlendirilmesi gerekliliği göz önüne alınmıştır. Bu çalışmanın temel amacı öğretmen adayları için dijital okumaya yönelik olarak geçerli ve güvenilir bir tutum ölçeği geliştirmektir.

\section{YÖNTEM}

$\mathrm{Bu}$ araştırmada bilgi çağının bir sonucu olan dijitalleşme olgusu ve bu olgunun sonucunda ortaya çıkan dijital okumaya yönelik tutumu ölçen güvenilir ve geçerli bir ölçme arac1 geliştirilmek amaçlanmıştır. Araştırmada pilot uygulama sürecinde örneklem seçiminde herhangi bir modellemeye gidilmemiştir. Özellikle COVID-19 pandemisi sürecinde verilerin toplanması ölçütsel örneklemeyi zorlaştırmış ve kolay ulaşılabilen örnekleme yöntemini zorunlu kılmıştır. Bu kapsamda iki kamu üniversitesinin eğitim fakültesinde öğrenim gören öğretmen adayları örnekleme dahil edilmiştir. Her iki eğitim fakültesinin bütün bölümlerine ulaşılmış çalışmalar 3. ve 4. sınıf öğrencileri ile yürütülmüştür. A üniversitesinden 319 ve B üniversitesinde 169 öğretmen adayı çalışmaya dahil edilmiştir

Öncelikle yapı geçerliliği kapsamında yapılacak olan açımlayıcı faktör analizi (AFA) öncesi örneklemin yeterli olup olmasına dikkat edilmiştir. Ölçek geliştirme sürecinde çalışma grubunun faktör analizi tekniğinin kullanımı için önerilen madde sayısının beş katı örneklem büyüklüğü ölçütüne uygun olması gerekir (Child, 2006). Bu kapsamda ölçme aracının pilot uygulama öncesi soru sayısı baz alınarak 324 öğretmen adayından veriler toplanmıştır. Benzer şekilde Treece ve Treece (1982) ölçek geliştirme sürecinde pilot uygulama için 100 örneklemin yeterli olacağını öne sürmektedir. Bu kapsamda 324 sayısının açımlayıcı faktör analizi için yeterli düzeyde olduğu söylenebilir. Araştırma verileri araştırmacılar tarafından ölçme aracının online olarak uygulanması ile elde edilmiştir. Gerekli hazırlıklar yapıldıktan sonra öncelikle çevrimiçi bir ölçme aracı hazırlanarak öğretmen adaylarına iletilmiştir. Öğretmen adaylarına ölçme aracının amacı ve kapsamını açıklayıcı bilgilendirme çevrimiçi olarak yapılmış olup daha sonra ölçme aracını doldurmaları istenmiştir. Her bir örnekleme ölçme aracını doldurmaları için yeterli süre verilmiş̧tir. Yeterli süreyi belirlemede pilot uygulama öncesi 16 öğretmen adayına ölçme aracı uygulanmış ve bitirme sürelerinin ortalaması alınmıştır. İstek olmadan doldurulacak ölçmek formlarının güvenirliği olumsuz etkileneceğinden ölçekler gönüllülük esasına dayalı olarak uygulanmıştır. Ölçme aracı uzman görüşleri sonrası taslak form haline getirilmiş ve Google Form aracılığ 1 ile uygulama yapılmıştır. Öncelikle taslak form hazırlanmış, daha sonra 
kişisel bilgiler eklenerek ölçek son halini almıştır. Öğretmen adaylarına bilgilendirici (amaç, doldurma süresi ve doldurma tarzı gibi) bir metin de forma eklenmiştir. Araştırma kapsamında verilerin analizleri ölçme aracı geliştirme süreci basamaklarına uygun şekilde yapılmıştır. Öncelikle toplanan verilerin açımlayıcı faktör analizine (AFA) uygunluğunu tespit etmede KMO (Kaiser Mayer Olkin) analizi yapılarak örneklemin Açımlayıcı faktör analizi için yeterliliği belirlenmiştir. Daha sonra kayıp veriler incelenmiş ve ranjı artıran uç değerler Mahalanobis uzaklığı analizi ile tespit edilerek bu ölçekler veri setinden çıkartılmıştır. Mahalanobis uzaklığ analizi grupların farklı karakteristik özellikleri arasındaki ıraksaklık ve uzaklık olgularının tespitinde kullanılan bir analizdir (McLachlan, 1999, s. 20).

Ölçeğin analizleri geçerlik ve güvenirlik olmak üzere iki alt boyutta incelenmiştir. Ölçeğin geçerliliği kapsam ve yapı gibi iki aşamada incelenmiştir. Kapsam geçerliliğinde uzman görüşü alınmış; yap1 geçerliğini belirlemede ise AFA yapılmıştır. Hazırlanan ölçeğin güvenirliğini belirlemede ise öncelikle iki yarı güvenirlik yöntemine başvurulmuş daha sonra ise iç tutarlılığı belirlemek için Cronbach's Alpha güvenirlik yöntemi kullanılmıştır. Güvenirliği belirlemede ayrica Anova Tukey's Nonadditivity, Hotelling's T-Squared ve Intraclass Correlation Coefficient analizleri uygulanmıştır. Sonrasında doğrulayıcı faktör analizi (DFA) yapılarak analizlerin doğrulanması sağlanmıştır.

\section{BULGULAR}

\section{Ölçeğe gereksinim duyulması}

Bilgi çağında teknolojinin gelişmesi sonucu bireylerin iletişim araçları da değişiklik göstermiş̧ir. Bireyler basılı kitap, gazete ya da dergiden okumak yerine her zaman ve her yerde erişebildikleri dijital okumaya yönelmiştir. Bu kapsamda bireylerin dijital okuma tutumlarını değerlendirmek bir gereklilik hâline gelmiştir. Alan yazın incelendiğinde dijital okuma tutumu temalı bir ölçeğe rastlanmamıştır. Dijital Okumaya Yönelik Tutum Ölçeği geliştirilerek alan yazına anlamlı bir katkı yapılması düşüncesi oluşmuştur.

\section{Alan yazın taraması}

Alan yazın incelendiğinde her türlü eğitim düzeyinde okumaya yönelik tutum ölçeklerinin ve ekrandan okuma tutum ölçeklerinin olduğu tespit edilmiştir (Baştuğ ve Keskin, 2017; Bulut ve Karasakaloğlu, 2018; Güneş ve Susar Kırmızı, 2014; Sulak, 2019; Ulu, 2018). Ancak özel olarak öğretmen adaylarının dijital okuma tutumlarına yönelik bir ölçme aracına rastlanmamıştır.

\section{Taslak ölçek hazırlanması}

Alan yazın taraması sonrasında dijital okuma süreci dikkate alınarak, ekran okuma tutumu ve okuma tutumuna ilişkin ölçme araçları incelenerek maddeler oluşturulmaya çalışılmıştır. Diğer taraftan oluşturulan açık uçlu sorular ile 24 öğretmen adayına ulaşılmış ve soruları yanıtlamaları istenmiştir. Alan yazın taraması ve öğretmen adaylarından elde edilen yanıtlar doğrultusunda dijital okumaya yönelik tutumla ilgili yargılar oluşturulmuştur. Oluşturulan madde havuzunda 40 madde yer almıştır.

\section{Uzman görüşlerinin alınması}

Hazırlanan taslak ölçek gerek kapsam geçerliliğinin sağlanması gerekse yazım yanlışlarının giderilmesi amacıyla uzman görüşüne sunulmuştur. Taslak ölçek alanında uzman 7 ögretim elemanına sunulmuş ve uzman görüşüne başvurulmuştur. Bu süreçte taslak ölçek öncelikle iki Türkçe öğretmeni ve Türkçe Eğitimi ABD'de görev yapan bir öğretim elemanı 
tarafından incelenmiştir. Böylece ölçekteki yazım ve anlatımla ilgili sorunların tespiti ve düzeltilmesi yoluna gidilmiştir. Daha sonra ölçek alanında uzman 4 öğretim elemanına sunulmuştur Bu öğretim elemanları Eğitimde Ölçme ve Değerlendirme, Bilgisayar ve Öğretim Teknolojileri, Eğitim Programları ve Öğretim, Sınıf Öğretmenliği Anabilim Dalları'nda görev yapmaktadır. Uzmanlardan alınan dönütler sonrasında bazı maddeler çıkarılmış bazı maddelerde de düzeltmeler yapılmıştır. Böylece aday ölçekte 37 madde yer almıştır.

\section{Pilot uygulama öncesi ölçeğe son şeklini verme}

Uzman görüşü ile ortaya çıkan aday ölçeğe kişisel bilgiler formu ve ölçeği tanıtıcı bilgiler eklenmiştir. Ölçeğin skala sayısını belirlemek amacı ile yeniden uzmanlara başvurulmuş (ölçme ve değerlendirme, istatistik) ve 5'li skala (Kesinlikle katılıyorum, kısmen katılıyorum, kararsızım, kısmen katılmıyorum, kesinlikle katılmıyorum) kullanılmasına karar verilmiştir. Benzer şekilde Köklü (1995, s. 90) Likert ölçeklerde ikili, üçlü, dörtlü, altılı ve yedili seçenekler kullanılabileceğini ancak beşli skalanın en kullanışlı seçenek olduğunu belirtmektedir.

\section{Araştırma grubu}

Treece ve Treece (1982) ölçek geliştirme sürecinde pilot uygulama için 100 örneklemin yeterli olacağını öne sürmektedir. Crocker ve Algina'ya (1986) göre ise pilot uygulamada örneklem sayısı 100-200 arası olmalıdır. DOTÖ'yü geliştirme uygulamaları için AFA kapsamında 324; DFA kapsamında 164 olmak üzere toplamda 488 öğretmen adayına (195'i erkek, 293'ü kadın) ulaşılmıştır. Ölçek, Ege bölgesinde yer alan iki ayrı üniversitenin eğitim fakültelerinde 3 . ve 4 . sınıf öğrencilerine uygulanmıştır.

\section{Pilot uygulama}

Ölçeğin uygulanması gönüllülük esasına göre gerçekleştirilmiştir. Ölçeğin hitap ettiği kitle üniversite öğrencileri kısaca yetişkinlerdir. Ölçeğin pilot uygulamasının yapılması Covid19'dan dolayı sokağa çıkma kısıtlamalarının olduğu sürece (2020 Mart ve Nisan ayları) denk gelmiştir. Bu nedenle alınan sağlık tedbirlerine bağlı kalınarak ölçek internet üzerinden uygulanmıştır. Gerekli hazırlıklar yapıldıktan sonra öncelikle çevrimiçi bir ölçme aracı hazırlanarak öğretmen adaylarına iletilmiştir. Öğretmen adaylarına ölçme aracının amacı ve kapsamını açıklayıcı bilgilendirme çevrimiçi olarak yapılmış olup daha sonra ölçme aracını doldurmaları istenmiştir. Her bir örnekleme ölçme aracını doldurmaları için yeterli süre verilmiştir. Yeterli süreyi belirlemede pilot uygulama öncesi 16 öğretmen adayına ölçme arac1 uygulanmış ve bitirme sürelerinin ortalaması alınmıştır. Pilot uygulama sonrası veriler Excel, Lisrel ve SPSS 22 programları kullanılarak analiz edilmiştir. Bu kapsamda öncelikle kayıp veriler düzeltilmiş (eksik doldurulan ya da doldurulmayan formlar çalışma kapsamı dışında tutulmuştur) ve veriler analize uygun hâle getirilmiştir.

\section{Örneklemde uç değerlerden arınma}

Uygulanan taslak ölçekler AFA öncesi ön kontrol kapsamında incelenmiştir. Ranj1 artıran uç değerler tespit edilerek söz konusu formlar analiz dışı bırakılmıştır. Özellikle tüm maddelere 1 ya da 5 gibi uç değerler tanımlandığında bu durum ranjı artırmakta dolayısıyla da güvenirliği azaltmaktadır. Bu kapsamda örneklemde yer alan formların Mahalanobis uzaklık değerleri belirlenmiş ve 0.001 'den küçük olan üç form analizden çıkarılarak uygulama uç değerlerden arındırılmıştır (Tabachnick ve Fidell, 2001). Mahalanobis analizine ilişskin bilgiler Tablo 1'de gösterilmiştir.

Tablo 1: Mahalanobis Uç Değerler Analizi

\begin{tabular}{|c|c|c|c|c|}
\hline $\begin{array}{c}\text { Anket } \\
\text { Numarası }\end{array}$ & $\begin{array}{l}\text { Mahalanobis } \\
\text { Deŏeri }\end{array}$ & SS & $\begin{array}{l}\text { Minimum } \\
\text { Değer }\end{array}$ & Maksimum Değer \\
\hline
\end{tabular}




\begin{tabular}{|c|c|c|c|}
\hline & 2,529 & 132,5625 & 138,7647 \\
\hline 15 & 0.00037 & & \\
\hline 98 & 0.00083 & & \\
\hline 311 & 0.00011 & & \\
\hline
\end{tabular}

Tablo 1'e bakıldığında 324 form arasından 3 tanesinde uç değerlerin yüksek olduğu tespit edilmiş ve 15, 98 ve 311 numaralı formlar analiz dışı bırakılmıştır. 321 form üzerinden örneklem uygunluğuna bakılmıştır.

\section{Örneklem uygunluğu}

Toplanan formların açımlayıcı faktör analizi için yeterli olup olmadığını belirlemede Kaiser-Meyer-Olkin testi kullanılmıştır. Kaiser-Mayer-Olkin testine ilişkin bilgiler Tablo 2'de gösterilmiştir.

Tablo 2. KMO Analizine İlişkin Bilgiler

\begin{tabular}{lrr}
\hline \multicolumn{2}{l}{ KMO ve Bartlett's Test } & \\
\hline \multicolumn{2}{l}{ Kaiser-Mayer-Olkin Measure of Sampling Adequacy } &, 818 \\
\hline Bartlett's Test of Sphericity & Approx. Chi-Square & 11081,716 \\
\cline { 2 - 3 } & \multicolumn{1}{c}{ Sig. } &, 666 \\
\cline { 2 - 3 } & &
\end{tabular}

Tablo 2'ye bakıldığında örnekleme ilişkin KMO değerinin 0.818 olduğu görülmektedir. KMO değerinin 0.7 'den büyük olması durumunda örneklemin faktör analizi için yeterli olduğu söylenebilir (Seçer, 2013, s. 119). Bartlett's küresellik testi sonuçları da 0.05 'ten küçük ve anlamlı düzeydedir. Bu kapsamda seçilen örneklem büyüklügünün açımlayıcı faktör analizi için yeterli olduğunu ifade etmek mümkündür.

\section{Açımlayıcı faktör analizi}

Açımlayıcı faktör analizinin ilk basamağına uygun bir şekilde maddelerin ortak faktör varyansları tespit edilmiştir. Elde edilen veriler Tablo 3 'te verilmiştir.

Tablo 3: Madde Ortak Faktör Varyansları

\begin{tabular}{cccccc}
\hline Madde & Başlangıç & Çıkan & Madde & Başlangıç & Çıkan \\
\hline 1 & 1,000 &, 564 & 20 &, 388 &, 370 \\
\hline 2 & 1,000 &, 564 & 21 &, 688 &, 669 \\
\hline 3 & 1,000 &, 673 & 22 &, 724 &, 705 \\
\hline 4 & 1,000 &, 060 & 23 &, 569 &, 445 \\
\hline 5 & 1,000 &, 461 & 24 &, 571 &, 545 \\
\hline 6 & 1,000 &, 596 & 25 &, 648 &, 624 \\
\hline 7 & 1,000 &, 142 & 26 &, 653 &, 525 \\
\hline 8 & 1,000 &, 749 & 27 &, 561 &, 164 \\
\hline 9 & 1,000 &, 433 & 28 &, 598 &, 447 \\
\hline 10 & 1,000 &, 807 & 29 &, 589 &, 578 \\
\hline 11 & 1,000 &, 388 & 30 &, 638 &, 607 \\
\hline 12 & 1,000 &, 308 & 31 &, 637 &, 632 \\
\hline 13 & 1,000 &, 379 & 32 &, 546 &, 531 \\
\hline 14 & 1,000 &, 404 & 33 &, 591 &, 378 \\
\hline 15 & 1,000 &, 348 & 34 &, 703 &, 672 \\
\hline 16 & 1,000 &, 547 & 35 &, 300 &, 213 \\
\hline 17 & 1,000 &, 684 & 36 &, 509 &, 464 \\
\hline 18 & 1,000 &, 399 & 37 &, 758 &, 644 \\
\hline 19 & 1,000 &, 695 & & & \\
\hline
\end{tabular}


Tablo 3'e bakıldığında madde faktör yüklerinin 0,30' dan yüksek olması beklenmektedir (Seçer, 2013, s. 129-130). Tablo 3'e göre madde 4, 7, 27 ve 35'in madde faktör yük değerlerinin 0.30'dan küçük olduğu görülmektedir. Bu kapsamda dört madde madde faktör yük değerlerinin düşük olması nedeniyle ölçekten çıkarılmıştır. Temel bileşenler analizi (PCA) çok değişkenli bir analiz tekniği olup nicel değişkenlerin içsel ilişkileri hakkında bilgi edinilmesini sağlamaktadır (Abdi ve Williams, 2010, s. 433). Compenent matrix (bileşen matriksi) tablosu maddelerin faktörlere dağılımına ilişkin bilgi vermekte ve maddelerin faktör yük değerlerini göstermektedir. Maddelerin faktör yük değerlerine ilişkin bilgiler Tablo 4'te gösterilmiştir.

Tablo 4: Madde Faktör Yük Değerleri

\begin{tabular}{|c|c|c|c|c|c|}
\hline & \multicolumn{5}{|c|}{ Component Matrix $^{\mathrm{a}}$} \\
\hline & \multicolumn{2}{|c|}{ Bileşenler } & \multicolumn{3}{|l|}{ Bileşenler } \\
\hline Madde & 1 & 2 & Madde & 1 & 2 \\
\hline Madde10 & ,898 & - & Madde 33 & ,613 & - \\
\hline Madde 8 & ,846 &,- 192 & Madde 18 & ,605 &,- 196 \\
\hline Madde 22 & ,833 &,- 101 & Madde 11 & ,599 &, 169 \\
\hline Madde 19 & ,818 &,- 181 & Madde 28 &, 575 & ,355 \\
\hline Madde 21 & ,817 & - & Madde 1 &, 545 &,- 501 \\
\hline Madde 37 & ,806 & - & Madde 15 & ,505 &, 269 \\
\hline Madde 34 & ,798 &,- 193 & Madde 23 & ,501 & ,445 \\
\hline Madde 17 & ,788 &,- 260 & Madde 20 & ,484 & ,350 \\
\hline Madde 30 & ,785 & - & Madde 13 & ,455 &, 412 \\
\hline Madde 29 & ,761 & - & Madde 12 & ,432 &,- 337 \\
\hline Madde 24 &, 737 & - & Madde 2 & ,328 &,- 680 \\
\hline Madde 3 &, 737 &,- 359 & Madde 25 & ,425 & ,668 \\
\hline Madde 31 & ,736 &, 327 & Madde 26 & ,358 & ,661 \\
\hline Madde 32 & ,730 & - & Madde 6 & ,653 &,- 421 \\
\hline Madde 16 & ,693 &,- 233 & Madde 9 & ,630 &, 215 \\
\hline Madde 5 & ,682 & - & Madde 36 & ,618 & ,284 \\
\hline Madde 14 & ,308 & ,565 & & & \\
\hline
\end{tabular}

Maddelerin faktör yüklerinin 0,30'dan yüksek olması beklenmektedir. Tablo 4'e bakıldığında 3 ve 4 . maddeler dışında tüm maddelerin faktör yük değerlerinin 0,30'un üstünde olduğu görülmektedir. Bu nedenle ölçekten 3 ve 4. maddeler çıkarılmıştır. AFA'ya uygun bir şekilde döndürme işlemi yapılmış ve döndürülmüş madde matriksi (rotated component matrix) tablosu oluşturulmuştur. Döndürme işlemi sonrası binişik maddeler incelenmiştir. Tablo 5'ten elde edilen bilgiler 1şığında binişik madde bulunamamıştır. Binişik madde analizleri sonrası ölçeğe ilişkin döndürülmüş matriks verileri Tablo 5 'te gösterilmiştir.

Tablo 5: Döndürülmüş Madde Matriksi

\begin{tabular}{lll}
\hline Döndürülmüs madde matriksi & & \\
\cline { 2 - 3 } Maddeler & Bileşenler & 2 \\
\hline Madde 3 &, 811 & \\
\hline Madde 8 &, 809 & \\
\hline Madde 17 &, 798 & \\
\hline Madde 19 &, 779 & \\
\hline Madde 6 &, 777 & \\
\hline Madde 34 &, 769 & \\
\hline Madde 10 &, 751 & \\
\hline Madde 22 &, 747 & \\
\hline Madde 1 &, 732 & \\
\hline Madde 16 &, 704 & \\
\hline Madde 21 &, 687 & \\
\hline
\end{tabular}




\begin{tabular}{lll}
\hline Madde 37 &, 659 & \\
\hline Madde 30 &, 654 & \\
\hline Madde 2 &, 653 & \\
\hline Madde 24 &, 629 & \\
\hline Madde 29 &, 620 & \\
\hline Madde 18 &, 611 & \\
\hline Madde 32 &, 606 &, 791 \\
\hline Madde 33 &, 561 &, 748 \\
\hline Madde 12 &, 547 &, 684 \\
\hline Madde 5 &, 535 &, 649 \\
\hline Madde 25 &, 641 \\
\hline Madde 26 &, 616 \\
\hline Madde 31 &, 596 \\
\hline Madde 23 &, 582 \\
\hline Madde 14 &, 561 \\
\hline Madde 28 &, 531 \\
\hline Madde 13 &, 505 \\
\hline Madde 36 &, 476 \\
\hline Madde 20 & \\
\hline Madde 9 & \\
\hline Madde 15 & \\
\hline Madde 11 & \\
\hline a. Rotation converged in 3 iterations. & \\
\hline
\end{tabular}

Döndürme sonrası maddelerin faktör yük değerlerine bakıldığında (Tablo 5) Dijital Okumaya Yönelik Tutum Ölçeği (DOTÖ) iki alt ölçekten oluştuğu tespit edilmiştir. 1, 2, 3, 5, $6,8,10,12,16,17,18,19,21,22,24,29,30,32,33,34,37$ maddeler (21 madde) birinci alt ölçekte; $9,11,13,14,15,20,23,25,26,28,31$ ve 36 maddeler (12 madde) ise ikinci alt ölçekte yer almaktadır. Birinci alt ölçekte yer alan maddelerin faktör yük değerleri 0,81 ile 0,53 arasında; ikinci alt faktörde yer alan maddelerin faktör yük değerleri ise 0,79 ile 0,47 arasında değişmektedir. Ölçekte yer alan faktör sayısı aynı zamanda scree plot ile de tespit edilebilir. Yamaç birikinti grafiği (scree plot) faktör analizi sonunda elde edilen verilerin faktör sayısını belirlemede kullanılan bir yöntemdir (Kanyongo Gibbs, 2005, s. 122). Grafik 1'de scree plot eğrisi verilmiştir.

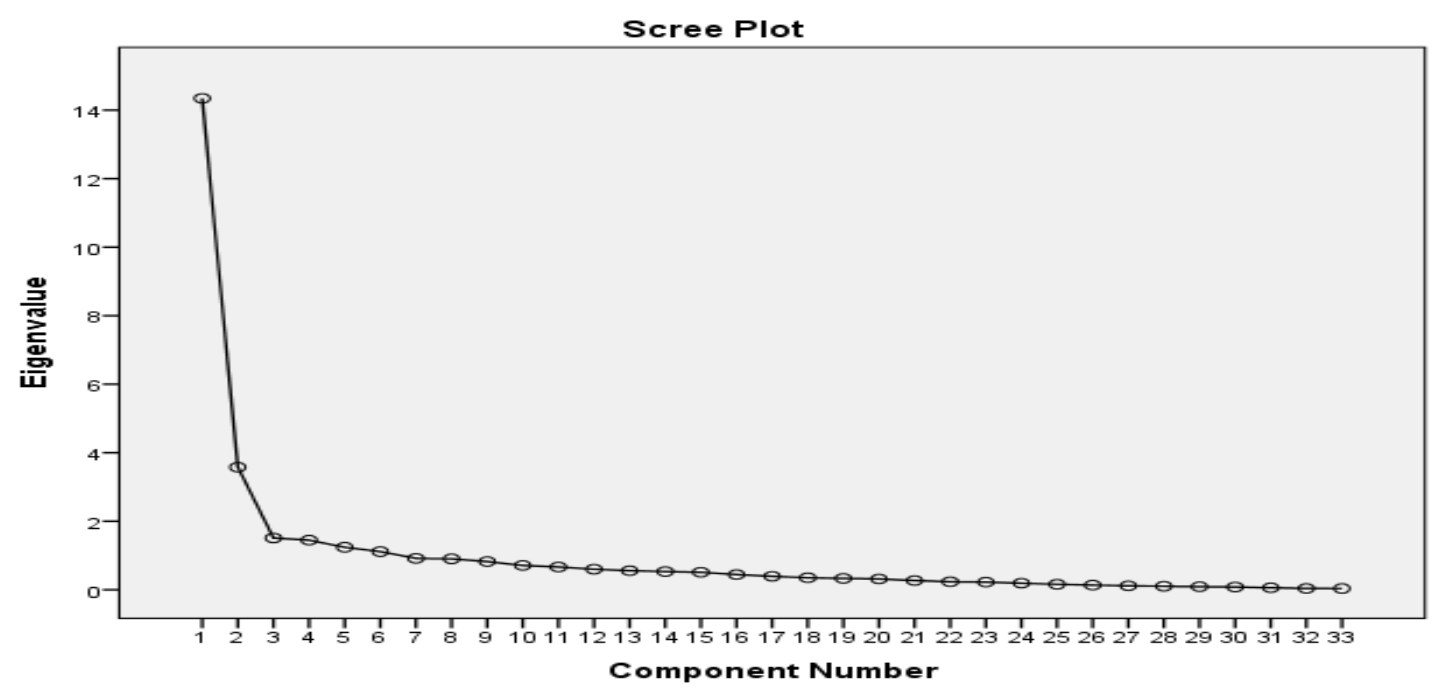

Grafik 1: Ölçekte yer alan alt ölçeklere ilişkin eğim grafiği 
Grafik 1'e göre DOTÖ'nün eğim noktaları baz alındığında ölçme aracının iki alt ölçekten oluşan bir yapıya sahip olduğu görülmektedir. DOTÖ'de yer alan faktörler, her bir alt ölçeğin açıklanma oranlarına ilişkin veriler ve toplam açıklanan varyanslara ilişkin bilgiler Tablo 6'da gösterilmiştir.

Tablo 6: Açıklanan Toplam Varyans Bilgileri

Toplam Açıklanan Varyans

\begin{tabular}{llllllll}
\hline Başlangıç Değerleri & \multicolumn{3}{c}{ Çıan kareler toplamı } & \multicolumn{3}{c}{ Döndürülmüş Kareler Toplamı } \\
\multicolumn{1}{l}{ Toplam Varyans } & Birikimli & Toplam Varyans & Birikimli & ToplamVaryans & Birikimli \\
\hline $114,344 \quad 43,467$ & 43,467 & 14,344 & 43,467 & 43,467 & 10,964 & 33,224 & 33,224 \\
\hline $23,577 \quad 10,838$ & 54,305 & $3,577 \quad 10,838$ & 54,305 & 6,957 & 21,081 & 54,305 \\
\hline \multicolumn{2}{l}{ Extraction Method: Principal Component Analysis. }
\end{tabular}

Tablo 6'ya bakıldığında ilk alt ölçeğin varyansının ölçeğin \%33,22'ini; ikinci alt ölçeğin varyansının ise ölçeğin \%21.08'ini açıkladığı görülmektedir. İki faktörün toplam açıkladığ varyans değeri ise \%54,30'dur. Güvenirlik analizleri öncesi 37 maddeden oluşan aday ölçekten toplamda 4 madde $(4,7,27$ ve 35. maddeler) çıkarılmıştır. Aday ölçek 33 madde ile güvenirlik analizlerine tabi tutulmuştur.

\section{Güvenirlik analizleri}

\section{Cronbach's Alpha değeri}

DOTÖ’nün güvenirliği için Cronbach's Alpha değerine bakılmıştır. Güvenirlik için birçok teknik kullanılmasına rağmen ölçek geliştirme süreçlerinde ve iç tutarlılığı tespit etmede en çok kullanılan teknik Cronbach's Alpha değerinin tespit edilmesidir (Sharma, 2016, s. 271). Tablo 7'de Cronbach's Alpha değerine ilişkin bilgiler gösterilmiştir.

Tablo 7: Cronbach's Alpha Değerine İlişsin Bilgiler

\begin{tabular}{ll}
\hline Cronbach's Alpha & Madde sayıs1 \\
, 954 & 33 \\
\hline
\end{tabular}

Tablo 7'ye göre ölçeğin geneline ilişkin Chronbach's Alpha katsayısının 0,95 olduğu görülmektedir. Bu değere göre ölçeğin iç tutarlılığının iyi bir düzeyde olduğu söylenebilir (Seçer, 2013, s. 179). Ölçekte yer alan 2 ve 14. maddeler ölçekten çıkarıldığında ölçeğin tümüne ilişkin Alpha güvenirlik değeri arttığından adı geçen maddeler ölçekten çıkarılmıştır. Böylece 33 maddelik DOTÖ 31 maddeye indirilmiştir. Maddelerin Chronbach's Alpha katsayısına etkisine yönelik veriler Tablo 8'de gösterilmiştir.

Tablo 8: Maddelerin Chronbach's Alpha Katsayısına Etkileri

\begin{tabular}{lcccl}
\hline & $\begin{array}{l}\text { Madde silindiğinde } \\
\text { oluşan ölçek } \\
\text { ortalamas1 }\end{array}$ & $\begin{array}{l}\text { Madde silindiğinde } \\
\text { oluşan ölçek varyans1 }\end{array}$ & $\begin{array}{l}\text { Düzeltilmiş madde } \\
\text { toplam } \\
\text { korelasyonu }\end{array}$ & $\begin{array}{l}\text { Madde silindiğinde } \\
\text { oluşan Cronbach's } \\
\text { Alpha değerleri }\end{array}$ \\
\hline Madde 1 & 118,6791 & 549,144 &, 509 &, 953 \\
\hline Madde 2 & 119,0872 & 560,455 &, 273 &, 955 \\
\hline Madde 3 & 118,4330 & 533,796 &, 697 &, 952 \\
\hline Madde 5 & 117,9377 & 537,902 &, 641 &, 952 \\
\hline Madde 6 & 118,3084 & 545,564 &, 607 &, 953 \\
\hline Madde 8 & 118,1495 & 531,890 &, 814 &, 951 \\
\hline Madde 9 & 118,2679 & 543,447 &, 609 &, 953 \\
\hline Madde 10 & 117,9720 & 526,596 &, 877 &, 950 \\
\hline Madde 11 & 118,3956 & 543,596 &, 582 &, 953 \\
\hline Madde 12 & 118,5981 & 557,597 &, 396 &, 954 \\
\hline
\end{tabular}




\begin{tabular}{lllll}
\hline Madde 13 & 118,1402 & 551,071 &, 440 &, 954 \\
\hline Madde 14 & 118,3769 & 558,698 &, 308 &, 955 \\
\hline Madde 15 & 117,9564 & 549,586 &, 497 &, 954 \\
\hline Madde 16 & 118,2773 & 541,895 &, 658 &, 952 \\
\hline Madde 17 & 117,8505 & 540,246 &, 750 &, 952 \\
\hline Madde 18 & 118,1651 & 546,413 &, 569 &, 953 \\
\hline Madde 19 & 117,8255 & 537,901 &, 781 &, 954 \\
\hline Madde 20 & 118,0156 & 550,128 &, 481 &, 951 \\
\hline Madde 21 & 117,7196 & 536,240 &, 780 &, 951 \\
\hline Madde 22 & 117,6262 & 537,360 &, 806 &, 954 \\
\hline Madde 23 & 117,9283 & 548,948 &, 498 &, 952 \\
\hline Madde 24 & 118,0218 & 536,015 &, 696 &, 954 \\
\hline Madde 25 & 118,4673 & 554,275 &, 426 &, 955 \\
\hline Madde 26 & 118,6168 & 555,043 &, 361 &, 953 \\
\hline Madde 28 & 118,3084 & 547,620 &, 559 &, 952 \\
\hline Madde 29 & 118,0779 & 538,628 &, 733 &, 952 \\
\hline Madde 30 & 118,0218 & 540,990 &, 749 &, 952 \\
\hline Madde 31 & 117,9221 & 542,616 &, 721 &, 952 \\
\hline Madde 32 & 118,0841 & 543,784 &, 707 &, 953 \\
\hline Madde 33 & 118,0312 & 545,462 &, 563 &, 952 \\
\hline Madde 34 & 117,9097 & 538,070 &, 754 &, 953 \\
\hline Madde 36 & 118,0498 & 542,760 &, 603 &, 779 \\
\hline Madde 37 & 117,7944 & 541,345 & & \\
\hline
\end{tabular}

İki madde çıkarıldıktan sonra ölçeğe ilişkin Chronbach Alpha değeri verileri Tablo 9'da gösterilmiştir.

Tablo 9: Madde Çıkarılma İşlemi Sonrası Cronbach's Alpha Değerine İlişkin Bilgiler Cronbach's Alpha ,956

\section{İki yarı güvenirlik analizleri}

Ölçeğin güvenirliğini belirlemede iki yarı güvenirlik analizi de kullanılmıştır. İki yarı güvenirlik analizinde ölçek seçkisiz olarak iki eşit parçaya bölünür ve bu iki yarılar arasındaki korelasyon değerine bakılır (Özbek, 2010, s. 57). İki yarı güvenirlik analizinde Spearman-Brown ve Guttman Split-Half değerleri de dikkate alınır. İki yarı güvenirlik analizine ilişkin bilgiler Tablo 9'da gösterilmiştir.

Tablo 9: Spearman-Brown ve Guttman Split-Half Değerlerine İlişkin Veriler

Güvenirlik İstatistikleri

Cronbach's Alpha

Bölüm 1

Değer

,917

Bölüm 2

Madde Sayıs1

$16^{\mathrm{a}}$

Değer

, 925

Toplam Madde Sayısı

İki bölüm arasındaki korelasyon katsayısı Madde Sayısı $\quad 15$

Spearman-Brown Coefficient

Eşit Uzunluklar

Eşit Olmayan Uzunluklar

Guttman Split-Half Coefficient

a. Maddeler: madde 1 , madde3, madde 5, madde 6, madde 8, madde 9, madde 10, madde 11, madde 12 , madde 13 , madde 15 , madde 16 , madde 17 , madde 18 , madde 19 , madde 20 .

b. Maddeler: madde 21, madde 22, madde 23, madde 24, madde 25, madde 26, madde 28, madde 29, madde 30 , madde 31 , madde 32 , madde 33 , madde 34 , madde 36 , madde 37. 
Tablo 9'a bakıldığında Spearman-Brown korelasyon değerinin 0,92 ve Guttman SplitHalf değerinin ise 0,923 olduğu görülmektedir. Bu kapsamda DOTÖ'nün iki yarı güvenirlik düzeyinin 0,92 olduğu tespit edilmiştir. Bu değer ölçeğin iki yarı güvenirliği açısından yeterli düzeydedir (Seçer, 2015, s. 27).

\section{Anova Tukey's Nonadditivity analizi}

Testi oluşturan maddelerin benzer yapılara sahip olduklarını, toplanabilirlik özelliğini ve homojenliğini belirlemek için Anova Tukey's Nonadditivity analizi yapılmıştır. Analize ilişkin veriler Tablo 10'da gösterilmiştir.

Tablo 10: Anova Tukey's Nonadditivity Analizine İlişkin Bilgiler ANOVA with Tukey's Test for Nonadditivity

\begin{tabular}{|c|c|c|c|c|c|c|c|}
\hline & & & Kareler Toplamı & $\mathrm{df}$ & $\begin{array}{l}\text { Kareler } \\
\text { Ortalamas1 }\end{array}$ & $\mathrm{F}$ & p. \\
\hline Kişiler Arası & & & 5580,827 & 320 & 17,440 & & \\
\hline \multirow[t]{5}{*}{ Within People } & Between & & 680,615 & 30 & 22,687 & 29,789 &, 000 \\
\hline & Residual & Nonadditivity & $59,726^{\mathrm{a}}$ & 1 & 59,726 & 79,059 &, 000 \\
\hline & & Balance & 7251,659 & 9599 & ,755 & & \\
\hline & & Total & 7311,385 & 9600 &, 762 & & \\
\hline & Total & & 7992,000 & 9630 &, 830 & & \\
\hline Total & & & 13572,827 & 9950 & 1,364 & & \\
\hline
\end{tabular}

a. Tukey's estimate of power to which observations must be raised to achieve additivity $=-, 475$.

Tablo 10'a bakıldığında $\mathrm{p}$ değerinin anlamlı olduğu görülmektedir $(\mathrm{p}<0,001) . \mathrm{Bu}$ kapsamda DOTÖ'yü oluşturan maddelerin homojen bir yapı içerdiği ve birbiri ile ilişkili olduğu söylenebilir. Ayrıca Tukey Nonadditivity değerinin $\mathrm{p}=0,00$ olduğu görülmektedir. Bu bağlamda DOTÖ likert tipi toplanabilir bir ölçek özelliği göstermemektedir (Ö̈zdamar, 2013, s. 565).

\section{Hotelling's T-Squared analizi}

Ölçülmek istenen olgunun geliştirilen ölçme aracı ile etkili bir şekilde ölçülme derecesini belirlemeye yarayan Hotelling's T-Squared analizine ilişkin bilgiler Tablo 11'de gösterilmiştir.

Tablo 11: Hotelling's T-Squared Analizine İlișkin Veriler

\begin{tabular}{lllll}
\hline Hotelling's T-Squared & $\mathrm{F}$ & $\mathrm{df} 1$ & $\mathrm{df} 2$ & $\mathrm{p}$ \\
\hline 1597,504 & 48,424 & 30 & 291 &, 000 \\
\hline
\end{tabular}

Hotelling T değerine bakıldığında anlamlı düzeyde olduğu görülmektedir $(\mathrm{p}<0,001)$. $\mathrm{Bu}$ kapsamda DOTÖ’nün “dijital okuma tutumu” olgusunu ölçmede etkili olduğu söylenebilir. Ayrıca DOTÖ homojen yapıda sorulardan oluşan güçlü ve özgün bir ölçek olarak kabul edilebilir.

\section{Intraclass correlation coefficient analizi}

Intraclass Correlation Coefficient analizi ölçme aracını oluşturan maddelerin yap1 bakımından geçerliliği ve güvenilirliği hakkında bilgi veren bir analizdir. Intraclass Correlation Coefficient (ICC) analizine ilişkin bilgiler Tablo 12'de gösterilmiştir.

Tablo 12: Intraclass Correlation Coefficient Analizine İlişkin Veriler

\begin{tabular}{|c|c|c|}
\hline \multirow[b]{2}{*}{ Intraclass } & \multirow{2}{*}{$\begin{array}{l}\text { 95\% Confidence } \\
\text { Interval }\end{array}$} & \\
\hline & & F Test with True Value 0 \\
\hline Correlation ${ }^{\mathrm{b}}$ & Alt sınır Üst sınır & $\begin{array}{lll}\text { df1 } & \text { df2 } & p\end{array}$ \\
\hline
\end{tabular}




\begin{tabular}{llllllll}
\hline Tekli ölçümler &, 414 &, 376 &, 456 & 22,899 & 320 & 9600 &, 000 \\
Ortalama ölçümler &, 956 &, 949 &, 963 & 22,899 & 320 & 9600 &, 000 \\
\hline
\end{tabular}

Dijital Okumaya Yönelik Tutum Ölçeği, ICC kriterlerine göre analiz edildiğinde ölçek yarılarının varyansları ve toplam varyansları birbirleri ile benzerlik göstermektedir. $\mathrm{Bu}$ kapsamda DOTÖ, soruların sıralanışı ve yapı özellikleri bakımından geçerli ve güvenilir bir ölçme aracıdır. Test hem tek tek sorular bakımından tekli ölçümler $(\mathrm{p})<0,01$ hem de ortalama ölçüleri (p)<0.01 bakımından güvenilir bir yapı geçerliliğine sahiptir (Özdamar, 2013, s. 565). Ölçekte açımlayıcı faktör analizi sonrası 33 madde bulunmakta iken güvenirlik analizleri sonrası 2 madde daha çıkarılmıştır. Bütün bu analizle sonrasında DOTÖ'de 31 madde yer almaktadır. Faktör analizi sonrası ilk alt ölçekte 21; ikinci alt ölçekte 12 madde var iken güvenirlik analizlerinde 1 madde birinci alt ölçekten, 1 madde ise ikinci alt ölçekten çıkarılmıştır. DFA öncesi ölçeğin 31 maddeden (birinci alt ölçek 20; ikinci alt ölçek ise 11 madde) oluştuğu belirlenmiştir.

\section{Doğrulayıcı faktör analizi}

Açımlayıcı faktör analizi (AFA) sonucunda elde edilen modeli tekrar doğrulamak amacıyla doğrulayıcı faktör analizi (DFA) yapılmıştır. DFA analizi AFA'ya dâhil olmayan 164 örneklemden elde edilen verilerle gerçekleştirilmiştir. AFA kapsamında veri toplanan örneklem dışında farklı bir örneklemden bu veriler toplanmıştır. DFA sonuçlarını değerlendirmek için uyum indekslerine bakılmıştır. Bu noktada Ki-kare oranının serbestlik derecesine bölümü olan $(\chi 2 / d f)$, REMSEA, GFI, AGFI, CFI ve IFI gibi uyum indeksleri hesaplanmıştır. Belirlenen uyum indeksleri Seçer (2015) tarafından belirtilen değer aralıkları referans alınarak yorumlanmıştır. Uyum indekslerine ilişkin bilgiler Tablo 13 'te gösterilmiştir.

Tablo 13: Uyum İndekslerine İlişskin Bilgiler

\begin{tabular}{lllll}
\hline Uyum indeksleri & $\begin{array}{l}\text { Kabul } \\
\text { edilebilir } \\
\text { uyum }\end{array}$ & Mükemmel uyum & Değer & Yorum \\
\hline IFI & .90 ve üzeri & .95 ve üzeri & 0.92 & Kabul edilebilir uyum \\
\hline NFI & .90 ve üzeri & .95 ve üzeri & 0.89 & Kabul edilebilir uyum \\
\hline NNFI & .90 ve üzeri & .95 ve üzeri & 0.92 & Kabul edilebilir uyum \\
\hline RFI & .90 ve üzeri & .95 ve üzeri & 0.88 & Kabul edilebilir uyum \\
\hline IFI & .90 ve üzeri & .95 ve üzeri & 0.92 & Kabul edilebilir uyum \\
\hline PNFI & $.050-0.95$ & $.095-1.00$ & 0.83 & Kabul edilebilir uyum \\
\hline PGFI & $.050-0.95$ & $.095-1.00$ & 0.56 & Kabul edilebilir uyum \\
\hline CFI & .95 ve üzeri & .97 ve üzeri & 0.92 & Kabul edilebilir uyum \\
\hline GFI & .85 ve üzeri & .90 ve üzeri & 0.64 & Orta düzey uyum \\
\hline AGFI & .85 ve üzeri & .90 ve üzeri & 0.59 & Orta düzey uyum \\
\hline REMSEA & .050 ve altı & .080 ve altı & 0.12 & Mükemmel uyum \\
\hline $\mathrm{X}^{2 / s d}$ & 3'ten küçük & & $1193 / 433=2.75$ & Mükemmel uyum \\
\hline
\end{tabular}

DOTÖ, AFA sonrası 31 maddeden oluşan bir yapı göstermekteyken DFA analizi sonras1 yapılan incelemelerde uyum indekslerinin beklenilen düzeylerde çıktığ göre DFA sonucu herhangi bir madde ölçme aracından çıkarılmamıştır. Tablo 13'e bakıldığında DFA sonucunda elde edilen uyum indeksleri birlikte değerlendirildiğinde 31 maddelik DOTÖ' nün 2 faktörlü yapısının iyi düzeyde uyum gösterdiği söylenebilir. Birinci düzey doğrulayıcı faktör analizi sonucunda elde edilen yol şeması ve madde yap1 parametreleri Şekil 1'de gösterilmiştir. 


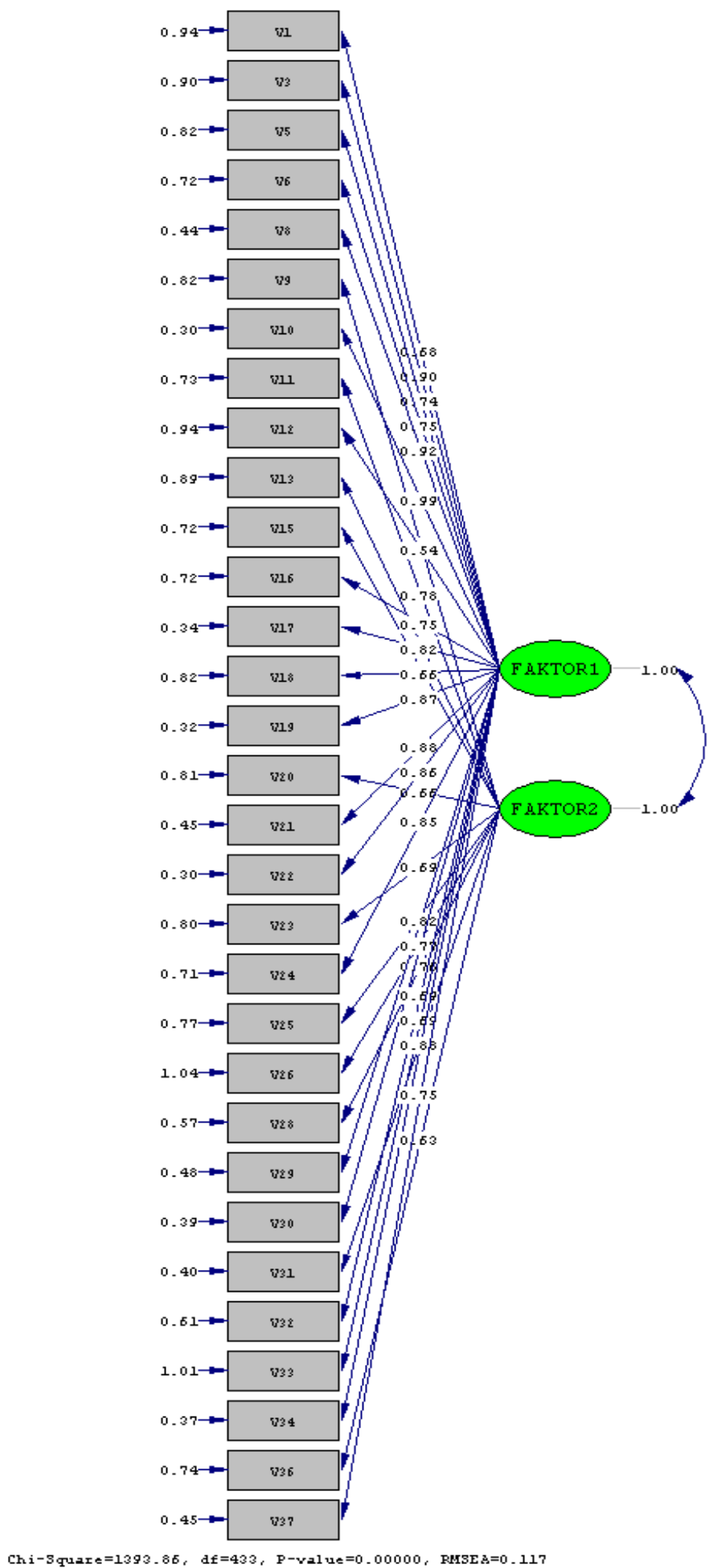

Şekil 1: Birinci Düzey Doğrulayıcı Faktör Analizi ile Elde Edilen Yol Şeması 
Şekil 1'de yer alan birinci düzey doğrulayıcı faktör analizi sonuçları ele alındığında ölçme aracında yer alan maddeler ile maddelerin ölçmeyi amaçladığı fenomenler arasındaki standartlaştırılmış faktör yüklerinin $\mathrm{t}$ değerine göre istatistiksel olarak anlamlı olduğu belirlenmiştir. Dolayısıyla ölçme aracında yer alan 31 maddenin puanlarının ölçeğinin tümünün yapısını oluşturan alt ölçekleri ölçtüğü ve faktöriyel geçerliği sağlandığı söylenebilir.

\section{Ölçeğe son şeklini verme}

Analizler sonucunda ölçekte yer alan her bir alt faktör isimlendirilmiş ve birinci alt faktöre "dijital okumanın özellikleri", ikinci alt faktöre "dijital okuma tercihleri" ismi verilmiştir. Ölçek 31 sorudan ve 5'li likert şeklinde oluştuğundan her soruya 1-5 arası puanlama verilerek ölçekten alınabilecek en yüksek puan 155, en düşük puan ise 31 olarak belirlenmiştir. Bu kapsamda 31-72 arası puanlara "düşük tutum"; 73-114 arası puanlara "orta düzey tutum" ve 115-155 arası puanlara ise "yüksek tutum" değerlendirmesi yapılması uygundur. Analizler sonucunda ölçeğin KMO değer 0.818; Cronbach's Alpha değeri 0,956; Spearman-Brown korelasyon değeri 0,92; Guttman Split-Half değeri 0,923; Anova Tukey's Nonadditivity ,000, Hotelling's T-Squared ,000 ve Intraclass Correlation Coefficient değeri ,000 bulunmuş olup ölçek iki alt ölçekten oluşmaktadır. İlk alt ölçek ölçeğin varyansının \%33,22'ini; ikinci alt ölçek ölçeğin varyansının ise \%21.08'ini açıkladığı görülmektedir. Birinci alt ölçekte yer alan maddelerin faktör madde yük değerleri 0,81 ile 1-0,535 arasında; ikinci alt faktörde yer alan maddelerin faktör yük değerleri ise 0,791 ile $-0,476$ arasında değişmektedir. İki faktörün toplam açıkladığ 1 varyans değeri ise $\% 54,30$ 'dur. Doğrulayıcı faktör analizi sonrası IFI değeri 0.92 ; NFI 0.89; NNFI 0.92; IFI 0.92; CFI 0.92; REMSEA 0.12 ve $\mathrm{X}^{2 / \mathrm{sd}}$ değeri 2.75 olarak belirlenmiştir. Ölçek son hâli ile iki alt ölçek ve 31 sorudan oluşmaktadır. Ölçme aracının son hali EK-1'de yer almaktadır.

\section{TARTIŞMA, SONUÇ VE ÖNERILLER}

Toplumsal yapıların temelini teşkil eden olgular, çağın belirleyicisi konumundadır. $\mathrm{Bu}$ kapsamda günümüzde bilginin en önemli olgu olduğu düşünüldüğünde bilgi çağında "bilgi ve bilgi edinme araçlarının” temel kaynaklar olduğu söylenebilir. Bilgi çağı ile birlikte birçok olgu da dönüşüme uğramıştır. Türkçe öğretiminin temel öğrenme alanları olan dinleme, konuşma, okuma ve yazma da bu çağ ile birlikte dönüşüme uğramıştır. Konuşma dijital konuşmaya (telefon ve internet odakl1) ve okuma dijital ya da ekrandan okumaya doğru bir evrim geçirmiştir. Yüz yüze konuşma yerini dijital konuşmaya bırakarak yer ve zaman gibi temel değişkenlerden bağımsız hale gelmiştir. Okuma da ekrandan okumaya doğru bir dönüşüm göstererek kısa sürede birçok kaynağa ulaşma ve okuma kolaylaşmıştır. Bu kapsamda günümüzde okuma sürecinin dijital ortamlarda yapılması irdelenmeye değer bir konudur. Gerek okumaya yönelik tutumu gerekse okuma başarısını belirlemede dijital değişim önemli bir yer edinmiştir.

$\mathrm{Bu}$ araştırmada da dijital okumaya yönelik olarak geçerli ve güvenilir bir tutum ölçeği geliştirilmeye çalışmıştır. Okumaya yönelik tutum alanında yapılan araştırmalara bakıldığında dijital ya da ekran boyutlarının dışarıda tutulduğu görülmektedir. Bunun pek çok nedeni olabileceği gibi dijitalleşmenin yaşama yönelik etkilerinin yeni olduğunu söylemek de yanlış olmaz. Okumaya yönelik tutum ile dijital okumaya yönelik tutumun farklı yapılar olduğu düşünülmektedir. Zaman içinde yapılacak bilimsel çalışmalarla bu durumun daha da netleşeceği düşünülmektedir. Nitekim dijital okumadaki unsurlar ile kitaptan okuma unsurları farklılaşmaktadır. Bu değişim, her iki okuma türünün yapılarını etkilemekte ve dijital okumaya yönelik farklı ölçme araçlarını geliştirmeyi zorunlu kılmaktadır.

DOTÖ'nün geliştirilmesinin alan yazına anlamlı bir katkı sağlayacağı düşünülmektedir. Ölçeğin geliştirilme sürecinde öncelikle taslak ölçek hazırlanmış ve uzman görüşleri alınmıştır. Uzman görüşleri sonrası ön uygulama yapılarak ölçeğin uygulanabilirliği test edilmiştir. Ölçme 
aracı yetişkinlere yönelik olduğundan 5'li Likert türü seçilmiştir. Ölçme aracının açımlayıcı faktör analizleri 324; doğrulayıcı faktör analizi ise 164 öğretmen adayının katılımı ile gerçekleştirilmiştir. Ölçeğin uygulanmasında toplamda 488 katılımcıya ulaşılmıştır. DOTÖ’nün pilot uygulamasının yapılması Covid-19 sürecine rastladığından öğretmen adayları ile birebir etkileşime geçilmemiş sağlık adına alınan tedbirlere bağlı kalınmıştır. Bu nedenle katılımcılara internet üzerinden ulaşma çabası içine girilmiştir. Araştırma verileri online ortamdan Google Forms ile toplanmıştır. KMO değeri 0.81 olup örneklem için yeterli olduğu görülmüştür. Analizler öncesi ranjı artıran uç değerler belirlenmiş ve bu formlar çıkarılmıştır. AFA sonrası ölçme aracından 4 madde çıkarılmış ve 37 maddelik taslak ölçek 34 maddeye inmiştir. Geçerlik analizleri sonrası öncelikle iki yarı güvenirlik analizi daha sonra ise iç tutarlılı̆g 1 belirlemede Cronbach's Alpha güvenirlik yöntemi kullanılmıştır. Güvenirliği belirlemede ayrica Anova Tukey's Nonadditivity, Hotelling's T-Squared ve Intraclass Correlation Coefficient analizleri yapılmıştır. Gerçekleştirilen güvenirlik analizleri sonrasında DOTÖ 34 maddeden 31 maddeye indirilmiştir. DFA analizi sonrası yapılan incelemelerde uyum indekslerinin beklenilen düzeylerde olduğu belirlenmiştir. Bu nedenle DFA sonucu herhangi bir madde ölçme aracından çıkarılmamıştır. Yapılan analizlere göre DOTÖ son hali ile 31 madde ve 2 alt ölçekten oluşmaktadır. Birinci alt ölçekte 20, ikinci alt ölçekte 11 madde yer almaktadır. İçerdiği maddelerin niteliği göz önüne alınarak birinci alt ölçeğe dijital okumanın özellikleri adı verilirken; ikinci alt ölçeğe de yine kapsadığı maddelere uygun bir şekilde dijital okuma tercihleri adı verilmiştir. DOTÖ 24 olumlu maddeden oluşmakla birlikte ölçme aracında 7 olumsuz madde yer almaktadır.

Etik Kurul İzin Bilgisi: Bu araştırma, T.C. Pamukkale Üniversitesi Sosyal ve Beşeri Bilimler Araştırma ve Yayın Etiği kurulunun 26/08/2020 tarihli 93803232-622.02/say1lı kararı ile alınan izinle yürütülmüştür.

\section{KAYNAKÇA}

Abdi, H. ve Williams, L.J. (2010). Principal component analysis. WIREs Computational Statistics, 2, 433-459.

Asutay, H., Atik, O., Öğretmen, S. ve Göçerler, H. (2016). The new reading types occurring as a result of changing youth cultures. The International Journal of Research in Teacher Education, 7(1), 28-39.

Ata, R. ve Alparslan, M.M. (2019). İnternet tabanlı okuma motivasyonu ve etkileşim ölçeği Türkçeye uyarlama çalışması ve öğretmen adayları ile bir inceleme. Eğitim Teknolojisi Kuram ve Uygulama, 9(2), 522-538.

Aydoğdu, Ö. (2012). Investigating the correlation between reading attitudes and academic success of elementary students with structural equation modelling. International Social Science Education of Journal, 2(1), 62-74.

Baştuğ, M. (2014). The structural relationship of reading attitude, reading comprehension and academic achievement. International Journal. Social Science \& Education, 4(4), 931946.

Baştuğ, M. ve Keskin, H.K. (2017). Kâğıttan dijitale yazma tutumu ölçeği güvenirlik ve geçerlik çalışması. Eğitim Teknolojisi Kuram ve Uygulama, 7(2), 58-72.

Birkerts, S. (1996). Reading in the electronic era. Logos, 7(3), 211-214.

Boz, S. (2018). Öğrencilerin dijital okuma kültürü. https://yegitek.meb.gov.tr Sitesinden 17. 05. 2020 tarihinde elde edilmiştir.

Bulut, B. ve Karasakaloğlu, N. (2018). Digital reading disposition scale: A Study of Validity and Reliability. Universal Journal of Educational Research, 6(4), 613-618.

Carvani, A., Cartelli, A., Fini, A. ve Ranieri, M. (2008). Models and instruments for assessing digital competence at school. Tecnologie Didattiche, 48, 39-46. 
http://docplayer.it/8696490-

Valutare-la-modelli-teorici-e-competenza-digitalestrumenti-applicativi-assessing-digitalcompetence- theoretical-models-and-tools.html Sitesinden 11.05. 2020 tarihinde elde edilmiştir.

Child, D. (2006). The essentials of factor analysis. (3rd Edition). London: Continuum.

Chou, I.C (2011). Understanding on-screen reading behaviors in academic contexts: A case study of five graduate English-as-asecond-language students. Computer Assisted Language Learning, 25(5),1-23.

Crocker, L. ve Algina, J. (1986). Classical and modern test theory. New York: Holt, Rinehart \& Winston.

Çelik, A. (2013). M-öğrenme tutum ölçeği: geçerlik ve güvenirlik analizleri, Eğitim ve Öğretim Araştırmaları Dergisi, 2(4), 172-185.

Fabrigar, L.R., McDonald, T.K. ve Wegener, D.T. (2005). The origin and structure of attitudes. D. Albaraccin, B.T. Johnson, and M.P. Zanna (Edt.), The Handbook of atttitudes and attitude change içinde, pp. 79-124. Mahwah, NJ: Erlbaum.

Güneş, F. ve Susar Kırmızı, F. (2014). E-kitap okumaya yönelik tutum ölçeğinin (EKOT) geliştirilmesi: Geçerlilik ve güvenirlik çalışması. Bartın Üniversitesi Eğitim Fakültesi Dergisi, 3(2), $196-212$.

Jacobs, G.E. (2013). Multi, digital or technology? Journal of Adolescent \& Adult Literacy, 57(2), 99-103.

Kanyongo, Gibbs Y. (2005). Determining the correct number of components to extract from a principal components analysis: A monte carlo study of the accuracy of the scree plot, Journal of Modern Applied Statistical Methods, 4(1), 120-133.

Katz, I.R. ve Macklin, A.S. (2007). Information and communication technology (ICT) literacy: Integration and assessment in higher education. Systemics, Cybernetics and Informatics, 5(4), 50-55.

Köklü, N. (1995). Tutumların ölçülmesi ve likert tipi ölçeklerde kullanılan seçenekler. Ankara Üniversitesi Ĕ̈itim Bilimleri Fakültesi Dergisi, 28(2). 81-93.

Liu, Z. (2008). Paper to digital. London: Greenwood Publishing.

Liu, Z. (2012). Digital reading. Chinese Journal of Library and Information Science, 5(1), 8594.

Mangen, A., Walgermo, B.R. ve Bronnick, K. (2013). Reading linear texts on paper versus computer screen: Effects on reading comprehension. International Journal of Educational Research, 58, 61-68.

Makhoul, B. ve Copti-Mshael, T. (2015). Reading comprehension as a function of text genre and presentation environment: Comprehension of narrative and informational texts in a computer-assisted environment vs. print. Psychology, 6(8), 1001-1012.

McKenna, M.C., Kear, D. ve Ellsworth, R.A (1995). Children's attitudes toward reading: A national survey. Reading Research Quarterly, 30, 934-956.

McLachlan, G.J. (1999). Mahalanobis distance. Resonance, 4(6), 20-26.

Morris, C.G. (2015). Psikolojiyi anlamakpsikolojiye girişs (Melike Sayı1, H. Belgin Ayvaşık, Çev.). Ankara: Türk Psikologlar Derneği Yayınları.

Odabaş, H, Odabaş, Z. ve Sevmez, H. (2018). Üniversite öğrencilerinde dijital / e-kitap okuma kültürü: Selçuk Üniversitesi örneği. DTCF Dergisi, 58(1), 139-171.

Özbek, Ö.Y. (2010). Ölçme araçlarında bulunması istenen nitelikler, Eğitimde ölçme ve değerlendirme içinde (S. Tekindal, Ed.), 44-87, Ankara: Pegem Akademi. 
Özdamar, K. (2013). Paket programlar ile istatistiksel veri analizi-II, (çok değişkenli yöntemler), (9. bs), Eskişehir: Nisan Kitabevi.

Özel, N. (2013). Araştırma görevlilerine bilgi ve iletişim teknolojileri bağlamında bilgi okuryazarlı̆̆ becerilerinin kazandırılması. Yayımlanmamış Doktora Tezi, Ankara Üniversitesi Sosyal Bilimler Enstitüsü, Ankara.

Özerbaş, M.A. ve Kuralbayeva, A. (2018). Türkiye ve Kazakistan öğretmen adaylarının dijital okuryazarlık düzeylerinin incelenmesi. MSKÜ Eğitim Fakültesi Dergisi, 5(1), 16-25.

Özgüven, İ.E. (2000). Psikolojik Testler, Ankara: PDREM Yayınları.

Pratkanis, A.R. and Greenwald, A.G. (1989). A sociocognitive model of attitude structure and function. Advances in Experimental Social Psychology, 22, 245-285.

Ross, C.S. (2002). Reading in a digital age. The digital factor in library and information services (G. E. Gorman, Ed.) içinde (s. 91-111), London: Facet Publishing.

Sallabaş, M.E. (2008). İlköğretim 8. sınıf öğrencilerinin okumaya yönelik tutumları ve okuduğunu anlama becerileri arasındaki ilişki. İnönü Üniversitesi Eğitim Fakültesi Dergisi, 9(16), 141-155.

Seçer, İ. (2013). SPSS ve LISREL ile pratik veri analizi: Analiz raporlaştırma. Ankara: Anı Yayıncilik.

Seçer, İ. (2015). SPSS ve LISREL ile pratik veri analizi: Analiz ve raporlaştırma. Ankara: Anı Yayıncilik.

Sharma, Balkishan. (2016). A focus on reliability in developmental research through Cronbach's Alpha among medical, dental and paramedical professionals. Asian Pacific Journal of Health Sciences. 3, 271-278. Doi: 10.21276/apjhs.2016.3.4.43.

Sulak, S.E. (2019). Dijital okuryazarlık ölçeğinin geliştirilmesi: geçerlik ve güvenirlik çalışması. Social Sciences Studies Journal, 5(3), 1329-1342.

Susar Kırmızı, F. (2017). Ekrandan okumaya yönelik tutum ölçeğinin (ekyötö) geliştirilmesi: Geçerlilik ve güvenirlik çalışması. International Journal of Languages' Education and Teaching, 5(1), 286-301.

Şahenk Erkan, S.S., Balaban Dağal, A. ve Tezcan, Ö. (2015). Öğretmen adaylarının yazılı ve dijital okuma alışkanlıklarının değerlendirilmesi. Uluslararası Eğitim Bilimleri Dergisi, 2(2), 122-134.

Tabachnick, B.G. ve Fidell, L.S. (2001). Using multivariate statistics (4. ed.). Boston: Ally and Bacon.

Tavşancıl, E. (2014). Tutumların ölçülmesi ve spss ile veri analizi. Ankara: Nobel Yayın Dağıtım.

TDK (2017). Bilim ve Sanat Terimleri Ana Sözlüğü,http://www.tdk.gov.tr/index.php?option=com_bilimsanat\&arama=kelime\& guid=TDK.GTS.58e4f99c622a20.31145084 adresinden 12.03.2021 tarihinde erişilmiştir.

Treece, E. W. ve Treece, J.W. (1982). Elements of research in nursing (3rd ed.). St. Louis, MO: Mosby.

Ulu, H. (2018). Ekran okuma öz yeterlik ölçeği: Geçerlik ve güvenirlik çalışması. Ana Dili Eğitimi Dergisi, 6(1), 148- 165.

Yılmaz, M. (2009). Üniversite öğrencilerinin okuma alışkanlığı üzerine bir inceleme (Cumhuriyet Üniversitesi Eğitim Fakültesi Türkçe Eğitimi bölümü örneği). Çukurova Üniversitesi Eğitim Fakültesi Dergisi, 3(37), 144-167. 


\section{EXTENDED ABSTRACT}

A period has begun when the rules of reading, known for centuries, have changed. In this period, readers need to master new skills to meet the requirements of digital reading. For example, in this period when the information is reproduced in an uncontrollable way, it has been revealed that the readers need to evaluate the resources they have acquired in the context of accuracy and competence more than before. Another problem encountered in digital reading is technical problems that are frequently encountered. This situation saves time for the readers and may even lead to the termination of the reading act. Some problems that readers do not know and / or do not need to know, such as network connection problems, browser problems, plug-in deficiencies, screen-display incompatibilities, unwanted ads, cookies and pop-ups, are among the problems that alter and make the reading adventure of this period difficult (Odabaş, Odabaş and Does not like, 2018). Despite everything, it should not be overlooked that digital reading has its own ease and difficulties. The widespread use of digital reading, especially among young people, necessitates research in this field. It is not possible to say that there are sufficient numbers of national scales for digital reading. It is particularly important to evaluate the attitudes of teacher candidates towards this reading field. Having a positive or negative attitude of preservice teachers towards digital reading may also affect their students in the future. A teacher who loves digital reading effectively will most likely be a model for his student with this aspect. Therefore, it was taken into consideration that prospective teachers' attitudes towards digital reading should be evaluated with a valid and reliable scale. The main purpose of this study is to develop a valid and reliable attitude scale towards digital reading for prospective teachers.

In this study, it is aimed to develop a reliable and valid measurement tool that measures the digitalization phenomenon as a result of the information age and the attitude towards digital reading that arises as a result of this phenomenon. In the study, no modeling was used in sample selection during the pilot implementation process. Collecting data, especially during the COVID-19 pandemic process, made quantifiable sampling difficult and required an easily accessible sampling method. In this context, teacher candidates studying at the education faculties of two public universities were included in the sample. All departments of both education faculties were reached and the studies were carried out with 3rd and 4th grade students. 319 teacher candidates from University A and 169 from University B were included in the study. First of all, it was paid attention to whether the sample was sufficient before the exploratory factor analysis (EFA) to be carried out within the scope of construct validity. In order to use the factor analysis technique of the study group in the scale development process, it must comply with the sample size criterion of five times the number of items recommended (Child, 2006). In this context, data were collected from 324 pre-service teachers based on the number of questions before the pilot implementation of the measurement tool. Similarly, Treece and Treece (1982) argue that 100 samples will be sufficient for pilot implementation in the scale development process. In this context, it can be said that the number 324 is sufficient for exploratory factor analysis. Research data were obtained by the researchers by applying the measurement tool online. After the necessary preparations were made, firstly an online measurement tool was prepared and delivered to prospective teachers. Pre-service teachers were informed about the purpose and scope of the measurement tool online, and then they were asked to fill in the measurement tool. Enough time was given to fill in each sampling measurement tool. In determining the sufficient time, a measurement tool was applied to 16 pre-service teachers before the pilot application and the average of the completion times was taken. The 
scales were applied on a voluntary basis, as the reliability of the measurement forms that would be filled without request would be negatively affected. The measurement tool was turned into a draft form after expert opinions and was applied via Google Form. First, a draft form was prepared, then the scale was finalized by adding personal information. An informative text (such as purpose, filling time and filling style) was added to the form. Within the scope of the research, the analysis of the data was made in accordance with the steps of the measurement tool development process. First of all, KMO (Kaiser Mayer Olkin) analysis was performed to determine the suitability of the collected data to exploratory factor analysis (EFA) and the adequacy of the sample for exploratory factor analysis was determined. Later, the missing data were analyzed and extreme values increasing the range were determined by Mahalanobis analysis and these scales were removed from the data set. Mahalanobis analysis is an analysis used to determine the divergence and distance phenomena between different characteristics of the groups (McLachlan, 1999, p.20). The analysis of the scale was examined in two subdimensions as validity and reliability. The validity of the scale was examined in two stages such as scope and structure. Expert opinion was received for the scope validity; EFA was used to determine the construct validity. In determining the reliability of the prepared scale, the two-half reliability method was used first and then the Cronbach's Alpha reliability method was used to determine the internal consistency. Anova Tukey's Nonadditivity, Hotelling's T-Squared and Intraclass Correlation Coefficient analyzes were also applied to determine the reliability. Afterwards, the analyzes were verified by performing a confirmatory factor analysis (CFA).

As a result of the analysis, each sub-factor in the scale was named and the first subfactor was named "characteristics of digital reading" and the second sub-factor was called "digital reading preferences". Since the scale consists of 31 questions and a 5-point Likert, each question is scored between 1-5 and the highest score that can be obtained from the scale was determined as 155 and the lowest score as 31 . In this context, "low attitude" scores between 3172; It is appropriate to make a "medium level attitude" evaluation for 73-114 points, and "high attitude" for 115-155 points. As a result of the analysis, the KMO value of the scale was 0.818 ; Cronbach's Alpha value is 0.956; Spearman-Brown correlation value of 0.92; Guttman SplitHalf value of 0.923; Anova Tukey's Nonadditivity was found to be .000, Hotelling's T-Squared, 000 and Intraclass Correlation Coefficient value, 000, and the scale consists of two subscales. $33.22 \%$ of the variance of the first subscale scale; It is seen that the variance of the second subscale scale explains $21.08 \%$. The factor item load values of the items in the first subscale were between 0.81 and 1-0.535; The factor loading values of the items in the second sub-factor vary between 0.791 and -0.476 . The total variance value explained by the two factors is $54.30 \%$. IFI value after confirmatory factor analysis is 0.92 ; NFI 0.89; NNFI 0.92; IFI 0.92; CFI 0.92; REMSEA was determined as 0.12 and $\mathrm{X} 2$ / sd value was determined as 2.75 . The scale consists of two subscales and 31 questions in its final form. The final version of the measurement tool is included in appendix-1.

The facts that form the basis of social structures are the determinants of the age. In this context, when it is considered that knowledge is the most important phenomenon today, it can be said that "information and information acquisition tools" are the basic resources in the information age. With the information age, many phenomena have also been transformed. Listening, speaking, reading and writing, which are the basic learning areas of Turkish teaching, have also been transformed with this age. Speech has evolved from digital speech (phone and internet oriented) and reading to digital or screen reading. Face-to-face conversation has been 
replaced by digital speaking, making it independent of basic variables such as place and time. Reading also transforms from screen to reading, making it easier to reach many sources and reading in a short time. In this context, performing the reading process in digital environments today is worth exploring. Digital change has an important place in determining both attitude towards reading and reading success. In this study, a valid and reliable attitude scale towards digital reading has been tried to be developed. When looking at the researches conducted in the field of attitude towards reading, it is seen that digital or screen dimensions are excluded. There may be many reasons for this, and it would not be wrong to say that the effects of digitalization on life are new. It is thought that the attitude towards reading from the eyes and the attitude towards digital reading are different structures. It is thought that this situation will become clearer with scientific studies to be conducted over time. As a matter of fact, the elements of digital reading and the elements of reading from books differ. This change affects the structures of both types of reading and makes it necessary to develop different measurement tools for digital reading. It is thought that the development of DOTÖ will make a meaningful contribution to the literature. In the process of developing the scale, first of all a draft scale was prepared and expert opinions were taken. The applicability of the scale was tested by pre-application after expert opinions. Since the measurement tool is intended for adults, a 5-point Likert type was chosen. Exploratory factor analysis of the measurement tool 324; Confirmatory factor analysis was conducted with the participation of 164 pre-service teachers. In the implementation of the scale, a total of 488 participants were reached. Since the pilot implementation of DOTÖ coincided with the Covid-19 process, one-to-one interaction with the teacher candidates was not made, and the measures taken in the name of health were adhered to. For this reason, an effort has been made to reach the participants over the internet. Research data were collected online with Google Forms. The KMO value was 0.81 and it was found to be sufficient for the sample. Before the analysis, extreme values that increase the range were determined and these forms were removed. After EFA, 4 items were removed from the measurement tool and the 37-item draft scale was reduced to 34 items. After the validity analysis, first two semi-reliability analysis and then the Cronbach's Alpha reliability method was used to determine the internal consistency. Anova Tukey's Nonadditivity, Hotelling's T-Squared and Intraclass Correlation Coefficient analyzes were also performed to determine the reliability. After the reliability analysis, DOTÖ was reduced from 34 items to 31 items. In the examinations made after the CFA analysis, it was determined that the fit indices were at the expected levels. For this reason, the CFA result was not excluded from any item measurement tool. According to the analysis, the final version of DOTS consists of 31 items and 2 subscales. There are 20 items in the first and 11 items in the second. Considering the quality of the items it contains, the first subscale is called the features of digital reading; The second subscale was named digital reading preferences in accordance with the items it covers. While DOTS consists of 24 positive items, there are 7 negative items in the measurement tool. 